\title{
'Off With Their Heads': British Prime Ministers and the Power to Dismiss
}

\author{
ANTHONY KING AND NICHOLAS ALLEN*
}

The British prime minister's power to appoint and dismiss ministers is probably his most important single power. This article explores how prime ministers from Macmillan to Blair have used that power. The article considers the criteria that prime ministers use when choosing to appoint or dismiss individuals from office before examining the calculations and miscalculations that prime ministers have made in practice. Finally, the article analyses the way that prime ministers have exercised, in particular, their power to dismiss and finds that Thatcher was far more likely than others to sack cabinet colleagues on ideological or policy grounds. The article emphasizes that prime ministers' relationships with especially powerful ministers - 'big beasts of the jungle' - are crucial to an understanding of British government at the top.

There is universal agreement that the British prime minister's power to appoint and dismiss his or her fellow ministers is among his or her most important powers, probably his most important power. In appointing ministers, he or she shapes his government. In dismissing them, he does likewise. Merely possessing the power to dismiss individual ministers gives the prime minister far greater leverage over them than he or she would otherwise have. As Peter Hennessy puts it in The Prime Minister:

Here lies the true locus of prime ministerial primacy in terms of the primus over the pares. And the instrument of the power is, in Enoch Powell's vivid phrase, the equivalent of Henry VIII's axe ... In terms of firing ministers, it really can be a matter of off-with-their-heads, though political reality does limit the scope of wholesale butchery, at least. ${ }^{1}$

Richard Crossman, while still a long-serving member of Harold Wilson's cabinet, addressed an audience at Harvard in similar terms:

First of all, remember that each Minister fighting in the Cabinet for his Department can be sacked by the Prime Minister any day ... I am aware that I am there at the Prime Minister's discretion. The Prime Minister can withdraw that discretion on any day he likes without stating a reason. And there's nothing much I can do about it - except succeed, and so build up my own strength. ${ }^{2}$

* Department of Government, University of Essex; and Department of Politics and International Relations, Royal Holloway, University of London (email: Nicholas.Allen@rhul.ac.uk). The authors are grateful to David J. Page for research assistance relating to some of the earlier years of the period covered by this article; to Albert Weale and two anonymous referees for this Journal for helpful comments on an earlier draft. For another debt of gratitude, see fn. 29 below. Anthony King's early research into the British prime ministership was part-funded by the Economic and Social Research Council of the United Kingdom.

${ }^{1}$ Peter Hennessy, The Prime Minister: The Office and Its Holders since 1945 (London: Allen Lane, The Penguin Press, 2000), pp. 68-9.

2 Richard Crossman, Inside View: Three Lectures on Prime Ministerial Government (London: Jonathan Cape, 1972), p. 63. One of Margaret Thatcher's former cabinet colleagues made the same point using 
To imagine a prime minister deprived of his or her power of appointment and dismissal is to imagine the holder of a much diminished office.

In Britain, the power of the head of government to appoint and dismiss his or her fellow ministers is largely unfettered. The only severe constraint upon him or her - but it is severe is that the great majority of his appointments must be made from among the elected members of the House of Commons. ${ }^{3}$ In the United States, France, Sweden, Norway, the Netherlands, Belgium and Portugal, for example, serving government ministers may not simultaneously be members of the national legislature; if they are members of the national legislature at the time of their appointment, they must immediately vacate their seats. ${ }^{4}$ In other countries - Germany, Austria, Italy, Finland, Denmark and Japan, for example members of the cabinet may be members of parliament but need not be. ${ }^{5}$ In all of those countries, unlike in the United Kingdom, those making ministerial appointments have a degree of flexibility in reaching out beyond the ranks of legislators and even, in some cases, beyond the ranks of politicians and party members.

At the same time, however, British prime ministers are not constrained in ways that many other heads of government are. British prime ministers can appoint and dismiss more or less whomever they like. The decisions are theirs, and they can make them on more or less whatever basis they like. That is not so in many countries, especially those countries - a large proportion of the world's democracies - in which coalition governments rather than majority governments are the norm. In those countries, even if the head of government has the formal power to appoint and dismiss ministers, he or she is likely

\footnotetext{
(F'note continued)

similar language: 'We were all, at different times, antagonized by the way Margaret ran roughshod over Cabinet, but outsiders do not appreciate fully the patronage power of a Prime Minister who won a General Election in 1983 and then again in 1987. The only way you get into Cabinet is if the Prime Minister decrees it. The only way you can move up from being Minister of Agriculture to Foreign Secretary is if the Prime Minister ordains it. The politician who keeps in favour is not being unprincipled. He or she has to recognize that the Prime Minister will decide.' See Peter Walker, Staying Power: An Autobiography (London: Bloomsbury, 1991), p. 232.

3 The House of Commons Disqualifications Act 1975 limits to 95 the number of members of the House of Commons who may be appointed to ministerial office. The Ministerial and Other Salaries Act 1975 limits to 110 the total number of individuals who may be paid ministerial salaries. In other words, a British prime minister may appoint no more than fifteen ministers in the House of Lords unless either he is prepared to restrict the number of ministers in the House of Commons and/or one or more ambitious (and probably wealthy) individuals, whether MPs or members of the House of Lords, are prepared to work for nothing. At the time of the 1997 British general election, the standing orders of the Parliamentary Labour Party sought to restrict the freedom of choice of any incoming Labour prime minister by requiring him to appoint to his new cabinet all those who had been members of Labour's shadow cabinet when the party was in opposition and who were still MPs. However, the new prime minister, Tony Blair, ignored this rule to the extent of appointing two elected members of the former shadow cabinet to his government, but only as junior ministers outside the cabinet.

${ }^{4}$ See Torbjörn Bergman, Wolfgang C. Müller, Kaare Strøm and Magnus Blomgren, 'Democratic Delegation and Accountability: Cross-national Patterns', in Kaare Strøm, Wolfgang C. Müller and Torbjörn Bergman, eds, Delegation and Accountability in Parliamentary Democracies (Oxford: Oxford University Press, 2000), Table 4.9, pp. 150-1.

${ }^{5}$ On the five European countries mentioned in the text, see Bergman et al., 'Democratic Delegation and Accountability: Cross-national Patterns', Table 4.9, pp. 150-1. On Japan, see Tomohito Shinoda, Leading Japan: The Role of the Prime Minister (Westport, Conn.: Praeger, 2000), pp. 59-61. Although the heads of government in all of these countries are constitutionally permitted to appoint cabinet ministers who are not members of the legislature, it is unusual in some cases for them to do so. In Japan, for example, the great majority of cabinet ministers are also legislators.
} 
to be largely or wholly constrained by the need to negotiate individual appointments and portfolios with the leaders of the other parties in the coalition - and quite possibly with other leading figures in his or her own party. In Italy, the prime minister has usually 'played a very limited part in the choice of ministers, as their selection [has been] left to each party of the coalition within the quota of ministerial positions assigned to that party'. ${ }^{6}$ Similarly, in Austria, 'the Chancellor's power of nomination is restricted, as one of the principles of the Austrian coalition government is that each party has full autonomy in the selection of its cabinet members'. The same has historically been the case in such countries as the Netherlands, Denmark and Finland and even in France and Germany when the incumbent administration in one or other of those two countries has depended for its parliamentary majority on more than one party. Until recently, the Australian Labor party (ALP) and the New Zealand Labour party excluded the prime minister entirely from the selection process: the two parties' parliamentary caucuses elected all the members of the ALP and New Zealand Labour party cabinets. In 2007, however, Australia's newly elected Labor prime minister, Kevin Rudd, broke with tradition and chose his own cabinet. ${ }^{8}$

Moreover, whereas British prime ministers, like American presidents, take for granted their power to dismiss ministers from their cabinet, heads of government in many other countries are afforded no such luxury. They are constitutionally or customarily prevented from dismissing their colleagues, or, more commonly, are prevented from doing so by the exigencies of factional and coalition politics. Only three Japanese prime ministers in the six decades since the end of the Second World War have felt strong enough to dismiss a cabinet minister outright. ${ }^{9}$ The Italian prime minister 'has no constitutional power to sack individual ministers' and, even if he had, sacking ministers would normally precipitate the fall of his government. ${ }^{10}$ In Norway, it is also difficult for the Prime Minister to dismiss ministers not belonging to his or her own party without disrupting the often fragile compromises underlying the cabinet formation'. ${ }^{11}$ The case of the Netherlands is extreme but by no means untypical:

The Prime Minister [of the Netherlands] cannot remove a minister or 'reshuffle' the Cabinet by assigning ministers to other portfolios. The Prime Minister of the wartime government in exile [in London] twice dismissed a minister without even consulting the Cabinet, but he was

6 Maurizio Cotta, 'Italy: A Fragmented Government', in Jean Blondel and Ferdinand Müller-Rommel, eds, Cabinets in Western Europe, 2nd edn (Basingstoke, Hants.: Macmillan, 1997), pp. 136-56, at p. 149.

7 Peter Gerlich and Wolfgang C. Muller, 'Austria: Routine and Ritual', in Blondel and MüllerRommel, eds, Cabinets in Western Europe, pp. 157-70, at p. 164.

${ }^{8}$ The Australian Labor party and the New Zealand Labour party's traditional methods of choosing cabinet ministers are described in Patrick Weller, First Among Equals: Prime Ministers in Westminster Systems (Sydney: George Allen \& Unwin, 1985), pp. 74, 85-7. Kevin Rudd took advantage of Labor's overwhelming victory in the Australian federal election of November 2007 and, when he came to appoint his cabinet, simply bypassed his party's parliamentary caucus. See Peter Smith, 'Rudd unveils handpicked cabinet', Financial Times (London), 29 November 2007.

${ }^{9}$ Shinoda, Leading Japan, pp. 62-3.

${ }^{10}$ David Hine and Renato Finocchi, 'The Italian Prime Minister', in G. W. Jones, ed., West European Prime Ministers (London: Frank Cass, 1991), pp. 79-96, at p. 82. See also Cotta, 'Italy: A Fragmented Government', p. 149; and Donatella Campus and Gianfranco Pasquino, 'Leadership in Italy: The Changing Role of Leaders in Elections and in Government', Journal of Contemporary European Studies, 14 (2006), 25-40. Campus and Pasquino argue that in the second Italian republic those prime ministers who have led coalitions of parties to power - notably Silvio Berlusconi - have greater power to determine the composition of their cabinets than prime ministers who have not (pp. 32-3).

${ }^{11}$ Svein Eriksen, 'Norway: Ministerial Autonomy and Collective Responsibility', in Blondel and Müller-Rommel, eds, Cabinets in Western Europe, pp. 210-24, at p. 219. 
immediately criticized for such 'Persian constitutional morals' and after the war a parliamentary inquiry rejected the claim that the Prime Minister should have the power of dismissal. ${ }^{12}$

And no Dutch prime minister since then has sought to reassert that claim. The phrase 'Persian constitutional morals' hints at despotism, but every British prime minister enjoys precisely such despotic powers.

The British premier's capacious power both to appoint and to dismiss his or her fellow ministers has, of course, always been significant. H. H. Asquith's appointment of David Lloyd George as chancellor of the exchequer in 1908 tilted the balance of the then Liberal government sharply to the left, as Asquith knew it would, and accelerated the introduction of the British welfare state. Stanley Baldwin's unexpected appointment of Winston Churchill as chancellor in 1924 reinforced Baldwin's already declared determination to reunite the Conservative party and present it to the nation as a centrist party of good government. In 1929, the incoming Labour prime minister, Ramsay MacDonald, filled his diary with gloomy reflections on the importunities of ambitious office-seekers: 'I have broken hearts - one man all but fainted when I told him he could not get what he expected. ${ }^{13}$ Clement Attlee's cabinet appointments in 1945 did not indicate any disposition on his part to be a dominant prime minister, but they did indicate a clear determination to prevent civil war within the government by keeping two heavyweight figures who hated each other, Ernest Bevin and Herbert Morrison, out of each other's way.

All that is true. But it is also true that the prime minister's power of appointment and dismissal is almost certainly even more significant now than it was a century ago or even half a century ago. In the first place, governments are now larger than they used to be, with the prime minister having more posts to fill - and, of course, to empty. Gordon Brown appointed seventy-five House of Commons ministers in June 2007 compared with Ramsay MacDonald's thirty-eight in 1929 and Harold Macmillan's fifty-four as recently as $1957 .{ }^{14}$ In the second place, the incidence of career politicians - men and women who are not content to remain on the back benches but aspire to ministerial office - is almost certainly higher now than it was in previous generations. An old fact of the constitution the prime minister's power to hire and fire - has had added to it a new fact of political sociology:

The great majority of British politicians [nowadays] are career politicians. They eat, breathe and sleep politics. Most of them passionately want to be ministers; or, if they are already ministers, they want to be promoted in the ministerial hierarchy, and they certainly do not want to be demoted, shunted sideways or dismissed. It follows that the prime minister of the day is in an exceedingly powerful position. He or she is the monopoly supplier of a good, ministerial office, which is in ... short supply and for which there is an enormous demand. He or she can exploit this monopoly position to influence the behaviour of backbenchers who

\footnotetext{
${ }^{12}$ Rudy B. Andeweg and Galen A. Irwin, Governance and Politics of the Netherlands, 2nd edn (Basingstoke, Hants.: Palgrave, 2005), p. 122.

${ }^{13}$ Quoted in David Marquand, Ramsay MacDonald (London: Jonathan Cape, 1977), p. 491. MacDonald complained that he had had would-be ministers 'in here weeping and even fainting'. See Hugh Dalton, Call Back Yesterday: Memoirs, 1887-1931 (London: Frederick Muller, 1953), p. 217.

${ }^{14}$ Computed in the case of Gordon Brown from the House of Commons Information Office website and in the cases of Ramsay MacDonald and Harold Macmillan from David Butler and Gareth Butler, Twentieth-Century British Political Facts 1900-2000, 8th edn (Basingstoke, Hants.: Macmillan, 2000), pp. 12-13 and 26-9. The totals in each case include the government's law officers but exclude the government whips.
} 
want to be ministers and of ministers who want to be promoted and not to be dismissed ... The career politician's ambition is the ambitious prime minister's opportunity. ${ }^{15}$

Despite the centrality of the prime minister's appointment and dismissal power, academic political scientists have not paid much attention to it. They have noted its existence and have readily acknowledged its central importance, but few of them have investigated in any detail how prime ministers actually use their power. The treatment has tended to be highly generalized. Almost the only exception is a decades-old article, published in Parliamentary Affairs, by R. K. Alderman and J. A. Cross. ${ }^{16}$ The reasons for political scientists' reticence in this connection are obvious. Not only have prime ministers over the decades appointed and dismissed thousands of individual ministers, including hundreds of cabinet ministers, but they have had very little to say, at least publicly, about their reasons for making the decisions they have. In some cases, they have probably not wanted their reasons to be known. In others, they have probably been somewhat unclear themselves about their reasons or have at any rate not felt any need to articulate them. In any case, no prime minister could possibly allow himself to get into the position of having to explain and defend seriatim his appointment and dismissal decisions (not to mention his decisions to reshuffle).

Political scientists are, therefore, largely left to fend for themselves: to try to divine prime ministers' motives from what little they have said in public and from the political and personal circumstances that appear to have pertained at the time. In other words, gathering systematic evidence in this field is difficult, and knowing how to interpret the evidence - and how much reliance to place on one's own interpretations - is even more difficult. Still, a serious attempt is worth making. The subject is too important to be left as a kind of terra incognita or as a matter of mere gossip, anecdotage and speculation.

This article seeks in a modest way to open up the subject for enquiry. It explores the ways in which prime ministers have used their power to dismiss cabinet ministers over the last half century, during the period between 1957 and 2007. We acknowledge that the article is limited in scope and also limited in time, though a half-century's experience should be enough to point to a number of general conclusions. It is also limited to the prime minister's dismissal power and does not deal, except initially, with his or her powers to appoint, reshuffle and relocate. Because there are fewer outright dismissals, they attract more attention, and evidence bearing on them is therefore easier to obtain. In any case, the prime minister's power to dismiss ministers is, as the two quotations at the beginning of this article suggest, the prime minister's most formidable power, potentially at least, in his or her dealings with people who are already his ministerial colleagues. Finally, the article is limited to dismissals from - and, in a few instances, demotions from - the cabinet. It would be impossible to investigate in any detail prime ministers' reasons for sacking junior ministers: the sheer number of such dismissals has been very large, and in most cases the reasons underlying them were at the time, and remain, wholly obscure. Who knows or even wants to know why William Whitlock ceased to be parliamentary under-secretary of state at

15 Anthony King, 'The British Prime Ministership in the Age of the Career Politician', in Jones, ed., West European Prime Ministers, pp. 25-47, at p. 38. On the changing character of Britain's political elite, see Anthony King, 'The Rise of the Career Politician - And its Consequences', British Journal of Political Science, 11 (1981), 249-85; Peter Riddell, Honest Opportunists: The Rise of the Career Politician (London: Hamish Hamilton, 1993); and Peter Oborne, The Triumph of the Political Class (London: Simon \& Schuster, 2007).

${ }^{16}$ R. K. Alderman and J. A. Cross, 'The Reluctant Knife: Reflections on the Prime Minister's Powers of Dismissal', Parliamentary Affairs, 38 (1985), 387-407. 
the Foreign and Commonwealth Office on 13 October $1969 ?^{17}$ In any case, cabinet ministers are almost always more important both governmentally and politically than non-cabinet ministers.

\section{THE CRITERIA THAT PRIME MINISTERS USE}

However, before we narrow our focus to concentrate on ministers' departures from the cabinet, we need to consider in general terms the considerations that prime ministers take into account in making decisions about whether or not to employ particular individuals in their government and the calculations they make concerning their own political position relative to that of the individual or individuals they are thinking of employing - or not employing. Every prime minister makes, in effect, some kind of cost-benefit analysis every time he or she decides to appoint or dismiss someone. The cost-benefit analysis in question may be simple, or it may be complex; it may be made consciously, semi-consciously or largely unconsciously. But in some form or another it is bound to be made. At one extreme, the prime minister will know 'instinctively' what he or she wants to do or must do. At the other extreme, he or she may go to the trouble of writing out on the back of an envelope lists of pros and cons relating to the possible appointment or dismissal of named individuals.

It goes without saying, moreover, that, despite the emphasis on decisions concerning individuals in the preceding paragraph, the prime minister's cost-benefit analysis is almost certain to involve more than one individual. It will often, especially at the time a new government is formed or on the occasion of a major reshuffle, involve many. Given the limited number of places in the cabinet, to appoint $A$ means not appointing $B, C$ or $D$, and the prime minister must decide whether, under the circumstances, the appointment of $A$ (or $B$ or $C$ or $D$ ) is the most advantageous decision he can take. Similarly, if he or she is thinking of dispensing with the services of $X$, he must consider whether he or she and the government would be better or worse off if $X$ were replaced by $Y$ or $Z$. The costs and benefits are large in number and hard to weigh. It is no wonder that some prime ministers find it extraordinarily difficult - and often very uncomfortable - to make the necessary calculations. They sometimes act on impulse. Occasionally, a prime minister will delegate some of his or her own decisions to one or more subordinates. ${ }^{18}$

What criteria do prime ministers use in making decisions about ministerial appointments and dismissals? There would appear to be four sorts of criteria, though each of the four could easily be further refined and subdivided. The four overlap and are by no means mutually exclusive. ${ }^{19}$

17 At least in this case, it is possible to find out. Through no fault of his own, Whitlock found himself caught up in a dispute between two of Britain's then Caribbean colonies, the islands of St Kitts and Anguilla. The British government proposed that the two islands should form part of a merged dependency. The Anguillans objected and declared their independence, and when Whitlock arrived on the island to try to broker a deal he was chased off, shots having been fired. He lost his job as a consequence, though some at the time maintained that he was unfairly blamed for what had happened. See the obituary by Andrew Roth, 'William Whitlock: Loyal Labour MP who took the blame for a colonial humiliation', Guardian, 2 November 2001.

18 It was rumoured that towards the end of his premiership, Tony Blair left Downing Street aides to get on with the business of organizing the details of some of his reshuffles, at least with respect to junior ministers.

${ }^{19}$ The criteria listed here differ somewhat from those listed by other writers, notably in including presentational capacity and in placing less emphasis on intra-party balance. Richard Rose, in The Problem of Party Government (London: Macmillan, 1974), sets out 'at least three major criteria for making 
One is obviously governmental competence, the actual or possible future minister's ability to do the job in strictly Whitehall terms. Can he or she master a brief quickly? Can he or she master one at all? Can he or she deal with officials? Can he or she do business satisfactorily with the prime minister and his or her other ministerial colleagues? Can he or she contribute effectively (but not at too great length) to departmental and interdepartmental discussions, not least at formal cabinet and sub-cabinet meetings? Can he or she negotiate successfully with outside bodies and with Britain's fellow members of the European Union? And so on. Before appointing someone to a ministerial post, the prime minister, unless he happens to know an individual well, can obviously do little more than make the best guess he can as to whether the potential appointee possesses these qualities and, if so, in what combination. Would-be ministers do not have to fill in application forms, and there are no formal or even informal interviews. Of course, once someone has served in government, even in a relatively junior post, he or she will have acquired more of a track record. Even then, however, the prime minister may well have had little personal contact with the individual in question and in deciding whether to promote or dismiss him or her is likely to have to rely on the judgements of ministerial colleagues, the whips and even civil servants. In this kind of setting, rumour, prejudice, gossip and sheer happenstance can count for a lot.

A second criterion, which may or may not overlap with the first, is political utility. Does the minister or prospective minister bring political skills to the job? Does he bring with him political nous? More importantly, does he or she bring with him a political constituency, one supportive not only of the minister but of the government and ideally the prime minister? What is his or her standing, if he or she has one, in the governing party? What is his or her standing, in the improbable event that he or she has one, with the general public? How, if at all, is he or she rated by 'informed opinion'? How, more specifically, is he or she rated by specific sectoral publics such as the City, the judiciary or the medical or teaching professions? Alternatively, is the person in question politically or personally bad news, someone with whom the prime minister would prefer his government not to be associated? For obvious reasons, this political-utility criterion is often not important operationally: most would-be ministers, and even many actual ministers, do not possess a well-developed political persona or reputation, either positive or negative. Prime ministers seldom feel under great pressure either to appoint particular individuals or to retain them. The most notable exceptions to this general rule we shall return to later.

A third criterion, which may well overlap with either or both of the previous two, is presentational capacity. This particular criterion would once have related almost exclusively

\footnotetext{
(F'note continued)

ministerial appointments': 'representativeness in relation to political factions and tendencies as well as social origins', 'loyalty to the Prime Minister' and 'ministerial competence' (pp. 363-4). Rose offers a similar list in 'British Government: The Job at the Top', in Richard Rose and Ezra Suleiman, eds, Presidents and Prime Ministers (Washington, D.C.: American Enterprise Institute, 1980), pp. 1-49, at p. 5. Harold Wilson, in The Governance of Britain (London: Weidenfeld \& Nicolson and Michael Joseph, 1976), emphasized the desirability of having the various wings of the Labour Party represented in the cabinet and also the need to have ministers who could 'handle the House of Commons' and had 'a real rapport with the party nationally, and above all in the country' (p. 31). The fact that more recent writers have had less to say about ministers' role in the House of Commons and about the need to represent the various wings of the governing party may reflect the declining (though still by no means negligible) importance of the House of Commons, Margaret Thatcher's ruthless exclusion of most 'wets' from her cabinet and also the much reduced importance of organized (and even unorganized) factions inside the contemporary Labour party. Concerning parliament, Peter Riddell puts the point bluntly: 'The main arena of British political debate is now the broadcasting studio rather than the chamber of the House of Commons.' See Peter Riddell, Parliament under Blair (London: Politico's, 2000), p. 160.
} 
to parliament. Someone who could not perform with a minimal degree of competence in the House of Commons or the House of Lords was unlikely to make it into the government of the day and certainly not into the cabinet; and someone who, having been appointed to ministerial office, turned out to be incompetent in parliamentary terms, was unlikely to survive for long. The purely parliamentary dimension of presentational ability is undoubtedly still important, but since at least the 1990s it has been joined and perhaps even superseded by a mass-media dimension, one relating especially to radio and television. The minister who can hold his or her own with John Humphrys or James Naughtie on BBC Radio 4's Today programme or stand up to Jeremy Paxman on BBC 2's Newsnight is likely to survive and even thrive. The person who is inarticulate, careless or easily flustered in front of a microphone or camera is unlikely to do either.

The fourth criterion is policy compatibility: compatibility, that is, with the substantive views of the prime minister. Members of the governing party's awkward squad or adherents of one of its more extreme wings are unlikely to make it into the government (unless it is to silence them or buy them off); and ministers who are unhappy with central aspects of the government's policies, and who express their unhappiness in public, are unlikely to survive for long (or perhaps to want to survive for long). Fortunately, for most prime ministers, this is not a criterion they have to attend to often. Most ministers and potential ministers do not possess strongly held policy views that differ sharply from those of the prime minister and the majority of the cabinet, and, even if they do, they are likely to keep their dissentient views to themselves. ${ }^{20}$ Most upwardly mobile politicians, as the Americans say, 'get along by going along'. There are, however, exceptions, and we shall encounter several of them later.

Although the four criteria just listed do overlap - in the sense that someone who meets any one of them is likely to meet most of the others and also in the sense that success under any one of these headings is likely to contribute to success under the others - it is worth emphasizing that the four are, nevertheless, distinct. For example, Edward Heath retained Margaret Thatcher as secretary of state for education (1970-74) because she was competent in purely governmental terms and because he needed a woman in the cabinet, but she was politically superfluous (apart from being a woman), inept presentationally and increasingly out of sorts with the prime minister's policies, though she mostly kept the extent of her unhappiness to herself. To take a more recent example, John Prescott, Tony Blair's deputy prime minister for the whole of his period in office (1997-2007), was politically useful to Blair and had come to share his views on policy, but Blair was far from holding him in high regard in purely Whitehall terms and regarded him in presentational terms as being, at best, a mixed blessing.

In addition to these four main criteria, other considerations often come into play. Personal affection and its opposite are not the least of them. Harold Wilson liked Barbara Castle and was actually somewhat intimidated by her; he retained her in the government and promoted her during both of his administrations. But James Callaghan disliked her, found her irritating and sacked her the moment he took office. ${ }^{21}$ Margaret Thatcher's

\footnotetext{
${ }^{20}$ One cabinet minister who largely kept her views to herself was Margaret Thatcher during her time as a member of Edward Heath's cabinet. On Thatcher's uncharacteristic reticence during this period, see John Campbell, Margaret Thatcher: The Grocer's Daughter (London: Jonathan Cape, 2000), pp. $242-52$.

${ }^{21}$ On Harold Wilson's relationship with Barbara Castle, see Anne Perkins, Red Queen: The Authorized Biography of Barbara Castle (London: Macmillan, 2003), passim, and Ben Pimlott, Harold Wilson (London: HarperCollins, 1992), esp. pp. 334-8: 'Barbara ... would mother and scold him' (p. 335). On
} 
fondness for Cecil Parkinson almost certainly led her to promote him and to retain him in the cabinet for a time even though he became involved in an embarrassing personal scandal that would probably have caused any other prime minister to let him go almost at once. $^{22}$ Struggles for power can also make a difference. Tony Blair and Gordon Brown vied for power within the government during the whole of the 1997-2007 period. Blair could not sack Brown, but he used most of his numerous reshuffles to reinforce the position of his own people in the government and also, where he could, to sack, demote or marginalize those whom he regarded as Brown's allies. ${ }^{23}$

Some decisions concern only individuals, but, of course, as we noted a moment ago, every prime minister also has to have regard to the composition of his cabinet as a whole. Most prime ministers feel they have to take into account the balance of ideological and factional forces within the governing party. Harold Wilson was acutely sensitive to such matters, and even Margaret Thatcher, when she first took office in 1979, felt compelled to include Conservative 'wets' as well as her own supporters in her administration. Edward Heath was a rarity in seeming to feel he could ignore ideological and factional considerations; Enoch Powell had large followings in both the country at large and the Conservative party, but Heath ruthlessly excluded him. ${ }^{24}$ Although British prime

(F'note continued)

James Callaghan's dismissal of her, see Kenneth O. Morgan, Callaghan: A Life (Oxford: Oxford University Press, 1997), pp. 478-9 - 'she had no affection for Callaghan himself' (p. 479) - and Perkins, Red Queen, pp. 416-18: when Wilson resigned in 1976 'Barbara knew that of all the potential leaders [Callaghan] was the one with the least time for her' (p. 417).

${ }_{22}$ On Margaret Thatcher's relationship with Cecil Parkinson, see Hugo Young, One of Us: A Biography of Margaret Thatcher, final edn (London: Macmillan, 1991), pp. 313-15: 'He made a fussing, worried, preoccupied woman feel rather luxuriously at ease' (p. 315). On the circumstances of his retention in the cabinet, at least in the short term, see Young, One of Us, pp. 342-14. Parkinson's own account of his temporary retention and subsequent departure is contained in Cecil Parkinson, Right at the Centre: An Autobiography (London: Weidenfeld \& Nicolson, 1992), chap. 12. So fond was Thatcher of Parkinson, and so respectful was she of his abilities, that she restored him to cabinet office a few years later.

${ }^{23}$ For example, Andrew Rawnsley, an unusually well-informed journalist, notes that 'As the [July 1998] reshuffle was announced, it became clear that Blair was carpet-bombing the network of supporters Brown had placed in the government ... The partisan purpose of the exercise was underlined by Blair's refusal to give any balancing jobs to MPs, even of promotion-worthy ability, associated with Brown.' See Andrew Rawnsley, Servants of the People: The Inside Story of New Labour (London: Hamish Hamilton, 2000), pp. 163-4. Another well-informed journalist, James Naughtie, adds: 'At each following reshuffle, the counting went on: how many Blairites in, how many Brownites out?' See James Naughtie, The Rivals: The Intimate Story of a Political Marriage (London: Fourth Estate, 2001), pp. 116-17.

${ }^{24}$ Heath's exclusion of Powell gives the lie to the oft-repeated assertion that there are some individuals who are so powerful within their party that they are impossible to leave out. Although Powell undoubtedly had a substantial following in the Conservative party, and although Heath was well aware that he had one, Heath as party leader in opposition had already sacked him from the shadow cabinet following his famous 1968 anti-immigration 'rivers of blood' speech. To have nevertheless appointed him to the new Conservative cabinet in 1970 would have made the new prime minister look inconsistent, feeble and ridiculous and would also have incurred the ire of most of his senior colleagues and probably a majority of Conservative MPs. Not only would it have divided the parliamentary party, but some senior Conservatives, including Iain Macleod, would probably have refused to sit round the cabinet table with him. Fortunately for Heath, the strength of his position as the man who had just led the Conservative party to victory in a general election meant that he could afford to exclude Powell at virtually no cost to himself. Heath's account of Powell's behaviour in his memoirs - The Course of My Life: My Autobiography (London: Hodder \& Stoughton, 1998), pp. 290-4 - is excoriating. He adds that, after his sacking of Powell, 'We never spoke again' (p. 293). John Campbell, in his life of Heath, does not even 
ministers, unlike their counterparts in federal countries such as Austria, Australia, Canada and to a lesser extent Germany, are not under great pressure to appoint men and women from all parts of the country, they nevertheless avoid skewing their cabinet too conspicuously towards London and the southeast of England. Every cabinet contains northerners, at least one Scot and at least one Welsh person (even though, sometimes, when the Conservatives are in power, the individuals in question may represent English constituencies). ${ }^{25}$

Gender matters. Clement Attlee in his day could afford to say airily that 'nowadays, if you can, you should have some women in', but by the end of the twentieth century the presence of a number of women was deemed essential. ${ }^{26}$ Sexual orientation seems to matter less than it did; or at least gay men and women who have come out are clearly more acceptable than they once were. There is no pressure to include them, but equally there is no pressure to exclude them. Early in Tony Blair's administration, one of his Downing Street aides was heard to wonder aloud how many gay men Blair could afford to have in his cabinet. To have a very large number might make the cabinet look - how should he put it? - a little queer. He himself did not much care, but he did wonder. Age also matters. Quite apart from any tendency in recent years to value youth more highly than age, all prime ministers have every incentive to promote backbenchers into the government and to promote junior ministers within the government, and one obvious way to do that is to stand down older ministers and to appoint younger ones. Ambitious young men and women clamour to join the government. Older men and women are the least likely to feel aggrieved at being asked to go. ${ }^{27}$

(F'note continued)

bother to mention that Heath did not offer Powell a job; see John Campbell, Edward Heath: A Biography (London: Jonathan Cape, 1993), pp. 296-9. Powell himself 'realised immediately that, after Wilson, he had been the great loser of the election': Simon Heffer, Like the Roman: The Life of Enoch Powell (London: Weidenfeld \& Nicolson, 1998), p. 566.

25 Because of the Labour party's historic electoral predominance in Scotland and Wales, Labour prime ministers have seldom had any difficulty appointing competent ministers from those two nations. Conservative prime ministers have latterly found it more difficult. When John Major left office in 1997, the secretary of state for Wales sat for the English constituency of Richmond (Yorkshire). The political history of what used to be the German Democratic Republic has meant that, despite Angela Merkel, postreunification German chancellors have found it difficult to appoint more than a few cabinet ministers from that part of the Federal Republic.

${ }^{26}$ Clement Attlee is quoted in Francis Williams, A Prime Minister Remembers: The War and Post-war Memoirs of the Rt. Hon. Earl Attlee (London: Heinemann, 1961), p. 80. As recently as 1970, there was only one woman, Margaret Thatcher, in Edward Heath's cabinet. The cabinet that Tony Blair appointed in 1997 contained five women, and by the end of his time in office the number had increased to eight. His predecessor, John Major, was conscious of not having any women in his first cabinet but says in his memoirs that he did not want to engage in tokenism and instead appointed a number of women to junior ministerial office so that he could appoint women to the cabinet on merit in the future: John Major, The Autobiography (London: HarperCollins, 1999), p. 213. More generally, see Richard Cracknell, 'Women in Parliament and Government', House of Commons Library Standard Note: SN/SG/01250 (London: House of Commons, 2008).

27 That said, Barbara Castle (see fn. 21 above) felt mightily aggrieved at being asked to go. She recounts in her memoirs - Fighting All the Way (London: Macmillan, 1993), p. 489 - how the prime minister, James Callaghan, summoned her to tell her that he was not appointing her to his cabinet: 'I had, he said, to make way for younger people. I bit back the riposte: "Then why not start with yourself?" After all, he was two years younger than I and I was not seeking to be Prime Minister.' On the issue of age generally, see the brief reference in Samuel Berlinski, Torun Dewan and Keith Dowding, 'The Length of Ministerial Tenure in the United Kingdom, 1945-97', British Journal of Political Science, 37 (2007), 245-62, p. 258. 


\section{EXPLOITING THE POWER TO DISMISS}

With those general observations on the criteria that prime ministers use in making both appointments and dismissals by way of background, we now focus our attention exclusively on dismissals. From this point onward, our focus is on the ways in which, and the extent to which, different prime ministers used their dismissal power during the half century between 1957 and 2007.

If, however, we are to focus on dismissals, we need to be able to distinguish between two separate categories of ministerial departures. We need to be able to distinguish between those occasions on which departing ministers left the cabinet of their own volition and those on which the ministers who departed had no wish to go but whom the prime minister, by one means or another, forced to go. In other words, we need to be able to distinguish between occasions on which departing ministers jumped and those on which they were pushed. For that purpose, we need to examine the circumstances in which all of the ministers who left the cabinet between 1957 and 2007 actually did so.

Between Harold Macmillan's coming to office in January 1957 and Tony Blair's leaving it in June 2007, there were 132 occasions on which cabinet ministers left the cabinet for reasons other than their political party's loss of a general election, the loss of their own seat in the House of Commons or death. ${ }^{28}$ In order to find out why each of them left, we trawled the biographies, memoirs and diaries of upwards of four dozen former cabinet ministers as well as the large volume of biographies and memoirs of the eight prime ministers under whom they served. Usually one or more of these sources provided the answer to the question we were asking. When no answer was forthcoming, we consulted accounts of the relevant ministers' departures from office in the contemporary press. On one occasion, when even that source proved unhelpful, we approached the official biographer of a former prime minister to enquire about an individual. The biographer kindly telephoned the former prime minister, who, however, admitted that he could not recall why the individual had left the cabinet. ${ }^{29}$ In the end, we were left with only one person about whose departure from the cabinet there were such conflicting accounts that we felt unable to include him in our analysis. ${ }^{30}$

28 The number 132, like most of the other aggregate numbers in this article, is derived from the data set out in Butler and Butler, Twentieth-Century British Political Facts, and David Butler and Gareth Butler, British Political Facts since 1979 (Basingstoke, Hants.: Palgrave, 2006). The total of 132 departures includes instances when the departing cabinet minister, having served under one prime minister, ceased to serve under that prime minister's immediate successor even though the same political party remained in power. We take the view that, whatever the formal position, the politics of the situation, from both the departing ministers' point of view and the prime minister's, remains essentially the same.

${ }_{29}$ The official biographer in question was Kenneth O. Morgan, whose help we gratefully acknowledge. The former prime minister, who was in full possession of his faculties, was James Callaghan. The minister in question was Lord Shepherd (Malcolm Shepherd), the lord privy seal. We have no reason to doubt the statement in The Times' obituary of Lord Shepherd (6 April 2001) that he left the government simply in order to resume his business career.

${ }^{30}$ The one minister was David Hunt, who left John Major's government in 1995. On the one hand, one of Major's biographers suggests on the basis of private information that Hunt resigned for personal reasons and that Major had actually pencilled him in to move to another cabinet-level office; see Anthony Seldon with Lewis Baston, Major: A Political Life (London: Weidenfeld \& Nicolson, 1997), p. 589. On the other hand, contemporary press accounts flatly assert that he was sacked. For example, Andrew Marr wrote in the Independent (6 July 1995): 'The contrast with poor David Hunt is instructive. He got a job with similar potential last time round. He has been conspicuously, indeed excessively, loyal. He was Major's man. But he was also no good; so the Prime Minister quite brutally sacked him.' Although we 
Leaving that one minister aside, we then divided the remaining 131 departures into four categories: those occasions on which the individual left the cabinet largely voluntarily (i.e. jumped), those on which the individual left largely involuntarily (i.e. was pushed), those on which the individual resigned pre-emptively (i.e. jumped before being pushed) and - an especially small category - those occasions on which the individual was, to use the language of the law, 'constructively dismissed' (i.e. was placed by the prime minister in a position so awkward or humiliating that, without being formally dismissed, he felt compelled to resign). ${ }^{31}$

The ministers who left the cabinet largely voluntarily - a total of 44 - did so for a wide variety of reasons, including old age, ill health, the belief that they could make more money outside the government, a genuine desire to spend more time with their family and unhappiness at the prime minister's and the government's policies. To cite only a few examples, Iain Macleod and Enoch Powell refused to remain in Sir Alec DouglasHome's cabinet because they disapproved of the way in which Home had been chosen Conservative party leader; Frank Cousins, a former trade union leader, quit Harold Wilson's cabinet in 1966 in order to return to his union and because he was unhappy with government policy; Edmund Dell left James Callaghan's cabinet in 1978 because he did not much enjoy politics and preferred to return to the private sector; Michael Heseltine walked out of Margaret Thatcher's cabinet in 1986 because, although he did enjoy politics, he was furious with the prime minister for, as he maintained, treating him and the cabinet badly; and Robin Cook resigned from Tony Blair's cabinet in 2003 because he objected to the Blair government's decision to invade Iraq. ${ }^{32}$ This category, comprising those departing voluntarily, would be worth exploring in detail because such an exploration would throw light on (among other things) the changing structure of political careers in Britain; but, because our present focus is on prime ministers' use of their dismissal power, we do not pursue this line of enquiry here. A complete list of those whom we judge to have resigned voluntarily between 1957 and 2007 is set out in Appendix 1.

That leaves a total of 87 occasions when we believe the individual in question was dismissed outright, resigned pre-emptively or else was constructively dismissed. The names of all those individuals are set out in Table 1. They are divided within Table 1 into two categories: those whose dismissal, whatever precise form it took, had little or nothing to do with questions of policy or ideology and those whose dismissal was more closely related to substantive policy matters. Table 2 indicates the mean number of ministers leaving the cabinet, in toto, during each year of our various prime ministers' incumbency,

\footnotetext{
(F'note continued)

had on a number of occasions to exercise our own judgement, on no other occasion did we encounter such a stark conflict of evidence.

31 Leaving the case of David Hunt aside, the total number of departures was 131, but the total number of individuals who departed was only 126, five of them having departed twice: Cecil Parkinson (1983, 1990), Peter Brooke (1992, 1994), Peter Mandelson (1998, 2001), Alan Milburn (2003, 2005) and David Blunkett (2004, 2005).

32 See, in chronological order, Robert Shepherd, Iain Macleod (London: Hutchinson, 1994), chap. 13; Geoffrey Goodman, The Awkward Warrior: Frank Cousins, His Life and Times (London: Davis-Poynter, 1979), chap. 24; Robert Sheldon, 'Edmund Emanuel Dell', in H. C. G. Matthew and Brian Harrison, eds, The Oxford Dictionary of National Biography, Vol. 15 (Oxford: Oxford University Press, 2004), pp. 736-8; Michael Heseltine, Life in the Jungle: My Autobiography (London: Hodder \& Stoughton, 2000), chap. 15; and Robin Cook, The Point of Departure (London: Simon \& Schuster, 2003), chap 7.
} 
TABLE 1 Prime Ministerial Dismissals, Pre-emptive Resignations and Constructive Dismissals, 1957-2007

\begin{tabular}{|c|c|c|}
\hline Prime minister & $\begin{array}{l}\text { Dismissals on } \\
\text { non-policy grounds }\end{array}$ & $\begin{array}{l}\text { Dismissals on policy or } \\
\text { ideological grounds }\end{array}$ \\
\hline Harold Macmillan & $\begin{array}{l}\text { (12) } \\
\text { Gwilym Lloyd George (1957) } \\
\text { Lord Selkirk (1957)** } \\
\text { James Stuart (1957) } \dagger \\
\text { Patrick Buchan-Hepburn (1957) } \\
\text { Geoffrey Lloyd (1959) } \\
\text { John Maclay (1962) } \\
\text { Lord Kilmuir (1962) } \\
\text { David Eccles (1962) } \\
\text { Charles Hill (1962) } \\
\text { Selwyn Lloyd (1962) } \\
\text { Lord Mills (1962) } \\
\text { Harold Watkinson (1962) }\end{array}$ & $\begin{array}{l}\text { (1) } \\
\text { Antony Head (1957) }\end{array}$ \\
\hline Sir Alec Douglas-Home & $(0)$ & $(0)$ \\
\hline Harold Wilson (1964-70) & $\begin{array}{l}\text { (9) } \\
\text { Tom Fraser (1965) } \\
\text { Sir Frank Soskice (1966) } \\
\text { Douglas Houghton (1967) } \\
\text { Fred Lee (1967)* } \\
\text { Arthur Bottomley (1967) } \\
\text { Herbert Bowden (1967) } \\
\text { Patrick Gordon Walker (1968) } \\
\text { Judith Hart (1969)* } \\
\text { Anthony Greenwood (1969)* }\end{array}$ & $\begin{array}{l}\text { (2) } \\
\text { Douglas Jay (1967) } \\
\text { Richard Marsh (1969) }\end{array}$ \\
\hline Edward Heath & $\begin{array}{l}\text { (1) } \\
\text { Michael Noble (1970)* }\end{array}$ & $(0)$ \\
\hline Harold Wilson (1974-76) & $(0)$ & $(0)$ \\
\hline James Callaghan & $\begin{array}{l}\text { (4) } \\
\text { William Ross (1976) } \\
\text { Edward Short (1976) } \\
\text { Barbara Castle (1976) } \\
\text { Robert Mellish (1976) }\end{array}$ & $\begin{array}{l}\text { (1) } \\
\text { Roy Jenkins (1976)§ }\end{array}$ \\
\hline Margaret Thatcher & $\begin{array}{l}\text { (12) } \\
\text { Angus Maude (1981) } \\
\text { Baroness Young (1983) } \\
\text { David Howell (1983) } \\
\text { Cecil Parkinson (1983)† } \\
\text { Lord Cockfield (1984) } \\
\text { Peter Rees (1985) } \\
\text { Patrick Jenkin (1985) } \\
\text { Lord Hailsham (1987) } \\
\text { Michael Jopling (1987) } \\
\text { Lord Havers (1987) } \\
\text { John Moore (1989) }\end{array}$ & $\begin{array}{l}(10) \\
\text { Norman St John Stevas (1981) } \\
\text { Lord Soames (1981) } \\
\text { Sir Ian Gilmour (1981) } \\
\text { Mark Carlisle (1981) } \\
\text { Francis Pym }(1983) \\
\text { James Prior }(1984) \S \\
\text { John Biffen }(1987) \\
\text { Nigel Lawson }(1989) \S \\
\text { Nicholas Ridley }(1990) \dagger \\
\text { Sir Geoffrey Howe }(1990) \S\end{array}$ \\
\hline
\end{tabular}


TABLE 1 (Continued)

\begin{tabular}{|c|c|c|}
\hline Prime minister & $\begin{array}{l}\text { Dismissals on } \\
\text { non-policy grounds }\end{array}$ & $\begin{array}{l}\text { Dismissals on policy or } \\
\text { ideological grounds }\end{array}$ \\
\hline John Major & $\begin{array}{l}(14) \\
\text { Lord Belstead }(1990)^{*} \\
\text { Cecil Parkinson }(1990) \dagger \\
\text { Lord Waddington (1992) } \\
\text { Kenneth Baker (1992) } \\
\text { Tom King (1992) } \\
\text { Peter Brooke (1992) } \\
\text { David Mellor (1992) } \dagger \\
\text { Norman Lamont (1993) } \\
\text { John Patten (1994) } \\
\text { Lord Wakeham (1994) } \\
\text { Peter Brooke (1994) } \\
\text { John MacGregor (1994) } \\
\text { Jeremy Hanley (1995)* } \\
\text { Jonathan Aitken (1995) } \dagger\end{array}$ & $(0)$ \\
\hline Tony Blair & $\begin{array}{l}(20) \\
\text { David Clark (1998) } \\
\text { Harriet Harman (1998) } \\
\text { Lord Richard (1998) } \\
\text { Gavin Strang (1998) } \\
\text { Ron Davies (1998) } \\
\text { Peter Mandelson (1998) } \\
\text { Jack Cunningham (1999) } \\
\text { Peter Mandelson (2001) } \\
\text { Nick Brown (2001)* } \\
\text { Chris Smith (2001) } \\
\text { Ann Taylor }(2001) \\
\text { Stephen Byers }(2002) \dagger \\
\text { Lord Irvine (2003) } \\
\text { Andrew Smith (2004) } \dagger \\
\text { David Blunkett (2004)† } \\
\text { Paul Murphy (2005) } \\
\text { David Blunkett (2005) } \\
\text { Charles Clarke (2006) } \\
\text { Geoff Hoon (2006)* } \\
\text { Ian McCartney (2006)* }\end{array}$ & $\begin{array}{l}\text { (1) } \\
\text { Clare Short }(2003) \dagger\end{array}$ \\
\hline
\end{tabular}

*The ministers indicated by an asterisk were dismissed from the cabinet but were offered and accepted ministerial posts outside the cabinet.

$\dagger$ Pre-emptive resignation.

$\S$ Constructive dismissal.

the mean number of ministers who were dismissed and the mean number of those who were dismissed on policy-related or ideological grounds. The purpose of these tables is to enable us to see whether - reverting to Peter Hennessy's terminology - some prime ministers have been more prone than others to chop off their colleagues' ministerial heads. The purpose is also to see whether different prime ministers have assigned - or appear to have assigned - differing weights to policy matters in deciding whether or not to exercise their decapitation power. 
TABLE 2 Patterns of Departures from Cabinets, Dismissals by Prime Ministers, 1957-2007

\begin{tabular}{lccc}
\hline \hline & $\begin{array}{c}\text { Mean number } \\
\text { of departures } \\
\text { per year }\end{array}$ & $\begin{array}{c}\text { Mean number } \\
\text { of dismissals } \\
\text { per year }\end{array}$ & $\begin{array}{c}\text { Mean number of dismissals } \\
\text { per year on policy/ } \\
\text { ideological grounds }\end{array}$ \\
\hline Macmillan & 2.7 & 1.9 & 0.1 \\
Home & 2.0 & zero & zero \\
Wilson (1964-70) & 2.8 & 1.9 & 0.4 \\
Heath & 0.8 & 0.3 & zero \\
Wilson (1974-76) & zero & zero & 0.3 \\
Callaghan & 2.6 & 1.6 & 0.9 \\
Thatcher & 3.0 & 1.9 & zero \\
Major & 2.6 & 2.2 & 0.1 \\
Blair & 3.3 & 2.1 & \\
\hline \hline
\end{tabular}

Notes: The length of each prime ministership is measured in years to the nearest day. Thus, Margaret Thatcher served as prime minister for 11 years and 209 days or 11.57 years. The figures relating to each prime ministership are calculated on this basis. The category of 'departures' from the cabinet excludes deaths in office and ministers who lost their seat at an election, but it includes those ministers demoted to ministerial office outside the cabinet. It also includes David Hunt, whose departure we were unable to code. The category of 'dismissals' from the cabinet includes pre-emptive resignations, constructive dismissals and those ministers demoted to ministerial office outside the cabinet (see text relating to Table 1).

In a few cases, of course, it is open to dispute whether a specific individual departed voluntarily or under compulsion or whether an individual departed for reasons that should be coded as policy-related/ideological or for reasons that should be coded as nonpolitical. Two cases in point relate to the Westland affair of 1986, when two members of the cabinet abruptly departed within days of one another. In the case of Michael Heseltine, although Margaret Thatcher's behaviour provoked him beyond endurance, we code his departure as voluntary. The prime minister did not seek his resignation, did not realize how badly he thought she was treating him and was astonished when he went. In the case of Leon Brittan, we also code his departure as voluntary because, although his position had probably become untenable, the prime minister, Margaret Thatcher, professed that she did not want him to go and actually spent time trying to persuade him to stay. ${ }^{33}$ Questions could similarly be raised about our decisions to code the departures of Douglas Jay, Richard Marsh and Nicholas Ridley as policy-related/ideological. ${ }^{34}$

${ }^{33}$ See the nuanced account of Brittan's departure by Hugo Young in One of Us, pp. 453-4.

${ }^{34}$ Wilson described the scene of Jay's sacking in his memoir of his first government: 'We met in the station-master's office [at Plymouth] and, understandably, he took it badly ... But he was now over sixty, above the "retiring age" that I had informally laid down, except for very special cases.' See Harold Wilson, The Labour Government 1964-1970: A Personal Record (London: Weidenfeld and Nicolson, and Michael Joseph, 1971), p. 427. Wilson claimed that he sacked Jay for the reason just given, Jay's age, but no one believed him. Certainly, Jay did not. In his own memoirs - Douglas Jay, Change and Fortune: A Political Record (London: Hutchinson, 1980) - he insisted, partly on the basis of a conversation with an unnamed senior minister who had been involved, that 'the general public belief that my attitude on the EEC made it impossible for me to remain in this Government was basically correct' (p. 408). In any case, as Jay himself readily acknowledged, he was not strong enough politically to give Wilson cause for concern. Wilson's biographer, Ben Pimlott, agrees with Jay that his opposition to Britain's joining the 
However, the number of such contestable cases is, fortunately, quite few, sufficiently few not to disturb the central thrust of our conclusions.

Tables 1 and 2, taken together, suggest that, year on year, the average number of departures from British cabinets has tended to increase over the past half century. The average number of dismissals from the cabinet, as distinct from departures on other grounds, has also tended to increase. Thatcher dismissed her colleagues at the same high rate as Macmillan and Wilson (during the first of his two premierships); and both Major and Blair, year on year, dismissed more of their colleagues than any of their post-1957 predecessors. It would seem that in recent decades British politics at the top has become somewhat tougher and more turbulent than in the past. The explanation probably lies in some compound of prime ministers' increased ruthlessness and the inability of a gradually increasing number of ministers to meet the demands that the prime minister, the media and their sheer administrative workloads place upon them. It is also the case that longlived administrations of the same party have become more common in recent years, and prime ministers who have been in office for a considerable period of time, or whose party has been in office for a considerable period of time, are more likely than others to dismiss ministers who seem to them to have outlived their usefulness. ${ }^{35}$

But the most startling findings set out in Tables 1 and 2 concern the extent to which Margaret Thatcher stands out. Most prime ministers would appear to use their powers of appointment and dismissal to recruit and retain talent, to hold their party together and to

\section{(F'note continued)}

EEC was the root cause of his dismissal. He also agrees with Jay that by this time Jay was a largely isolated figure: 'When Wilson cut him down, he had no powerful defenders.' See Ben Pimlott, Harold Wilson (London: HarperCollins, 1992), pp. 467-8. On Richard Marsh, see his own account in Off the Rails: An Autobiography (London: Weidenfeld and Nicolson, 1978), chap. 9, where he attributes his dismissal from the cabinet to his opposition to the prime minister's support for the In Place of Strife proposals (see fn. 56 below). On Nicholas Ridley, see his account in 'My Style of Government': The Thatcher Years (London: Hutchinson, 1991), pp. 223-4. The Ridley case is certainly arguable. On the one hand, Thatcher let him go because he had gravely embarrassed the government by making offensive remarks about Germany and because he had already made known his intention to stand down at the next election. On the other, his reported remarks about Germany clearly cut athwart the government's approach to Britain's relations with Germany, which were meant to be businesslike if not exactly cordial. Thatcher, perhaps embarrassed by not having stood by Ridley, an old friend and ally, makes no mention of the episode in her memoirs. Hugo Young discusses the close relationship between the two of them in One of Us, pp. 572-3.

${ }^{35}$ Recent prime ministers have typically remained in office for considerably longer than most of their twentieth-century predecessors. Thatcher served for nearly twelve years, Major for more than six and Blair for almost exactly ten. Of the premiers covered in this article, only one other prime minister served as long: Macmillan, who held office for nearly seven years. The first-named premiers therefore had longer time in which to dismiss ministers and also to see them depart of their own accord. Largely for that reason, the average numbers of departures and dismissals reported in Table 2 conceal the fact that the absolute number of departures and dismissals was substantially greater during the second half of our period than during the first. During the twenty-five years following Macmillan's accession to the premiership in 1957, only 52 cabinet ministers left the cabinet, 35 of them having been dismissed. In contrast, during the ensuing twenty-five years, no fewer than 80 cabinet ministers left the cabinet, 52 of them having been dismissed. Premiers inheriting governments of their own party that have been in office for some time and premiers who have themselves been in office for some time have shown a marked disposition to sack an above-average number of ministers. Callaghan sacked five colleagues when he took over from Wilson in 1976 (Labour under Harold Wilson having been in power during much of the previous decade), and Gordon Brown in 2007 either sacked or showed no signs of wishing to re-employ no fewer than seven of Tony Blair's cabinet colleagues and demoted two others. Thatcher and Blair, during their last two years in office, each dispensed with the services of at least four of their colleagues. 
maximize their cabinet's appeal to the electorate. Margaret Thatcher, it would seem, was more single-minded. She wanted a cabinet that she found ideologically and temperamentally congenial, and she did not want a cabinet that contained men and women who stood in her way or who appeared likely to stand in her way. As the right-hand column in Table 1 shows, she sacked twice as many cabinet ministers on policy-related grounds as all of her post-1957 predecessors and successors put together; and she sacked almost as many cabinet ministers on policy-related grounds as on grounds of incompetence, age, scandal or whatever. She did not axe ministers at a significantly higher rate than several other prime ministers in our study, but she axed far more of them because, quite simply, they disagreed with her and she with them. Her behaviour reflected both the ideological divisions within the Conservative party during her time and her own determination, as she famously put it, 'to have togetherness': 'As Prime Minister, I could not waste time having internal arguments. ${ }^{36}$ Had she wasted time having internal arguments, it is at least arguable that she would not have accomplished as much as she did from her point of view.

\section{THE CALCULATIONS THAT PRIME MINISTERS MAKE}

In making decisions about whether or not to dismiss individual cabinet ministers, prime ministers inevitably make calculations, some of them delicate, a large proportion of them involving a substantial degree of uncertainty. Among other things, prime ministers calculate - they have no choice but to calculate - the strength of their own political position relative to that of the individuals they are considering dismissing. Their calculations in this regard may be accurate, or they may not be. Success and even survival for any prime minister depends in part on how shrewd and well informed he or she is in judging the balance of the political forces in play. Am I, or am I not, strong enough politically to oust that particular individual?

Many prime ministers over the past half century have been politically weak and have known they were weak. Sir Alec Douglas-Home inherited a divided Conservative party, many of whose members were doubtful about the legitimacy of his choice as party leader and also about his personal abilities. He was not in a position - and he knew he was not in a position - to sack any significant figure. ${ }^{37}$ Harold Wilson was in an immensely strong position - and knew he was - during the first three years of his 1964-70 premiership; but, following the 1967 devaluation of sterling, he was in a much weaker position - and was conscious that he was. ${ }^{38}$ Both James Callaghan, during all of his short premiership between 1976 and 1979, and John Major, during almost all of his long one between 1990 and 1997, knew that they were not personally strong enough to oust any of their senior colleagues, however exasperating they found them. ${ }^{39}$ Major thought several of his senior

36 Quoted in Hennessy, The Prime Minister, p. 401.

37 Of course, the position would have been transformed had Home led the Conservatives to victory at the 1964 general election. But in the meantime, he had to coexist, sometimes uncomfortably, with the man who had been widely expected to succeed Macmillan and who made no secret of the fact that he did not rate highly Home's intellectual abilities, R. A. Butler. See D. R. Thorpe, Alec Douglas-Home (London: Sinclair-Stevenson, 1996), esp. pp. 319-20.

38 On Wilson's loss of authority, especially following the devaluation of sterling in November 1967, see Pimlott, Harold Wilson, pp. 503-9. Pimlott writes (p. 509): 'Here was a new phenomenon in British politics: a prime minister with little support in the country, the press or the Government, who survived only because of the inertia of his party, and the lack of a mechanism for getting rid of him.'

39 How precarious Callaghan found his own position and that of his government during most of his premiership, following his brief honeymoon, is indicated by the tone and content of his memoirs, Time 
colleagues were 'bastards' (his word), but he recognized that if he got rid of any of them, his divided party would become even more fractious than it already was and that his position, already under threat, would be rendered even less secure. ${ }^{40}$ The political selfassessments of those four men were all accurate.

Intriguingly, the only post-1957 prime minister whose political position was impregnable, and who judged accurately that it was, was Edward Heath, who held office between 1970 and $1974 .^{41}$ Following the sudden death of his first chancellor of the exchequer, Iain Macleod, in the summer of 1970, Heath was secure in the knowledge that he had led his party to victory in the previous election, that he would almost certainly lead it to victory in the next election and that he had no serious rivals within his party for either power or influence. Partly for that reason, his was the most completely dominant premiership of the entire post-war period. Tony Blair occupied a roughly comparable position - and knew he did - throughout most of his long premiership, though, as we shall see later, his situation was constrained - and he knew it was constrained - in a way, and to an extent, that Heath's never was.

Prime ministers can, however, make mistakes. They may miscalculate. At the height of his power, Harold Macmillan was able in 1958 to dismiss as 'a little local difficulty' the resignation of his chancellor and two junior Treasury ministers, but four years later, when he sacked a third of his cabinet, he discovered to his cost that by this time his position was even less secure than he imagined it to be. But at least Macmillan did recognize that his position was insecure. ${ }^{42}$ Margaret Thatcher towards the end (as it turned out) of her premiership evinced no such recognition. In the first years of her time in office at the height of her power, she had sacked ministers - mostly so-called 'wet' Conservatives with impunity, and as time went on she seemed to suppose that her power was still at its

\footnotetext{
(F'note continued)

and Chance (London: Collins, 1987), esp. Part 5. At one point (p. 435), he notes that he was aware of two groups of ministers who, in a time of crisis, were discussing policy proposals at odds with those of the chancellor. He goes on: 'It was apparent that if the two groups were to coalesce the Chancellor [Denis Healey] would not have a majority for his negotiating stance. He was very hard-pressed throughout this period and I did not know what his reaction might be if the Cabinet overturned him ... [The] government could not have survived the resignation of the Chancellor.'

${ }^{40}$ A whole chapter of John Major's memoirs is actually entitled 'The "Bastards"': Major, The Autobiography, chap. 15. Major recounts (p. 343) that, gossiping with a television journalist before an open microphone that he did not know was open, he said: 'Just think it through from my point of view. You are the prime minister with a majority of eighteen, a party that is still harking back to the golden age that never was and is now invented. I could bring in other people. But where do you think this poison is coming from? From the dispossessed and the never-possessed. You and I can think of ex-ministers who are causing all sorts of trouble. Do we want three more of the bastards out there?' Newspapers quickly identified the three ministers they believed Major was referring to. Major sacked none of the three, though one subsequently resigned.

41 Anthony King makes that claim in The British Constitution (Oxford: Oxford University Press, 2007), p. 316. John Campbell in Edward Heath (p. 302) remarks apropos Iain Macleod's sudden death that 'Macleod was the one senior colleague with a mind of his own and the independence to stand up to the Prime Minister when necessary, to whose advice he would always have listened. It was increasingly a weakness of the Government that Heath was almost entirely surrounded by ministers who owed their position solely to himself'.

${ }^{42}$ On the events of January 1958 (the 'little local difficulty') and July 1962 (instantly dubbed 'the night of the long knives'), see Alistair Horne, Macmillan 1957-1986 (London: Macmillan, 1989), pp. 70-5 and chap. 12. Horne makes it clear that in 1962 Macmillan believed that, because of a sagging economy, poor local election results and poor opinion-poll ratings, both he and his government were in serious political trouble. On p. 340, he quotes Macmillan as writing in his diary, 'Our stock is low'.
} 
height. She failed to recognize, until it was too late, the numerous signs that it was waning. Her misreading of the strength of her position cost her her job. ${ }^{43}$

In making decisions about whom to sack, prime ministers thus estimate - accurately or inaccurately - their own strength; but of course, in addition, they must estimate - also accurately or inaccurately - the political strength and determination of others. Prime ministers' calculations are never absolute, peculiar to themselves; they are always relative, raising questions pertaining, to be sure, to themselves, but also to other politicians. Or at least their calculations, in their own interests, should always be relative.

Most cabinet ministers, it must be said, are expendable, and both the prime minister and the ministers in question know it. Despite their formal eminence and large motor cars, most ministers, even cabinet ministers, are relatively small creatures - gerbils, so to speak - in the political jungle. Their departure from office is likely to be agonizing for themselves, and, if their personal relations have been close, the business of sacking them may even be agonizing for the man or woman who sacks them. But otherwise nobody much notices. Most cabinet ministers' governmental competence is unremarkable and unlikely to be any greater than that of whoever succeeds them. Their political utility is likely to be minimal or non-existent. Their presentational skills are also likely to be unremarkable, and most of those who are inclined to disagree with the prime minister on policy matters usually keep their mouths shut; and, whether or not they do that, they are very likely - for the reasons just given - to be eminently dismissible from the prime minister's point of view. As Peter Hennessy said, in most cases it is merely a matter of 'offwith-their-heads'. Lest that judgement seem unduly harsh - or, worse, inaccurate - the reader is invited to peruse the relevant pages of the various editions of British Political Facts. Which prime minister paid any kind of political price, or even seemed likely to pay any kind of political price, for sacking (to name but a few) Fred Lee, Gordon Campbell, Stan Orme, Peter Rees, John Patten or David Clark? Even better known members of the cabinet than they were seldom have political clout sufficient to make a prime minister desist from sacking them if he or she is so minded.

Other ministers are more governmentally competent and do have some political utility and presentational capacity but can be dispensed with all the same. Douglas Jay was a well-known and reasonably competent minister, but Harold Wilson sacked him in 1967 because he thought Jay was a nuisance and believed, rightly, that Jay, once sacked, would not be in a position to make trouble. ${ }^{44}$ Barbara Castle was better known, better liked and at least as competent as Jay, but James Callaghan, newly installed as prime minister in 1976, reckoned, rightly, that he could sack her with impunity: his political position at that moment was impregnable, and she, although she had many personal and political friends,

43 The fullest account of Thatcher's political demise is Alan Watkins, A Conservative Coup: The Fall of Margaret Thatcher (London: Duckworth, 1991). Watkins provides ample evidence of the draining away of Thatcher's personal authority. For example, on pp. 8-9 he describes how one backbench MP, 'the Conservative Party's self-appointed parliamentary psephologist ... sniffed the air, produced his pocket calculator, put his finger to the wind and pronounced Mrs Thatcher dead.' Another Conservative MP, accused afterwards of exaggerating the rate at which the prime minister was losing support in the party, riposted: 'You weren't there, old boy, and you're talking absolute balls. Her support was turning away so

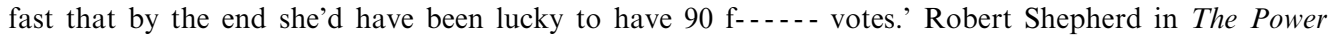
Brokers: The Tory Party and Its Leaders (London: Hutchinson, 1991) quotes yet another Conservative MP as saying 'that the talk about divisions in the party was true and that it wasn't the poll tax, it wasn't Michael Heseltine, it wasn't Europe, it was her' (p. 1).

${ }^{44}$ See fn. 34 above. 
had no substantial body of people who could truthfully be called political allies. ${ }^{45}$ In the aftermath of the Falklands War in 1983, Margaret Thatcher sacked her well-respected and popular foreign secretary, Francis Pym: she was then at the zenith of her power and calculated, rightly, that Pym was far too loyal and diffident to make trouble. ${ }^{46}$ Tony Blair was able to sack Charles Clarke as home secretary in 2006 despite the fact that his power as prime minister was already waning: he reckoned that he would pay a heavier price politically for keeping Clarke at that office than for moving him elsewhere or throwing him out. ${ }^{47}$ Instances such as these - of ministers who were not totally negligible but were nevertheless expendable - could be multiplied almost indefinitely.

However, there is a third category of ministers, much smaller than either of the other two, whom prime ministers, if they are well advised, treat more warily. This category comprises the men and women (mostly men) whom Conservative politicians several generations ago began to refer to as 'big beasts of the jungle'. ${ }^{48}$ Historically, there have been remarkably few such beasts. Of the 222 individuals who served in the cabinet in the half century between 1957 and 2007, probably fewer than two dozen should, in our view, be assigned to that category. ${ }^{49}$

${ }^{45}$ Her old friend Michael Foot, in particular, did try to persuade Callaghan to keep her in the administration, but neither Foot himself nor any other significant figure showed any signs of going public, let alone of resigning, if he let her go. See Morgan, Callaghan, pp. 478-9.

46 Thatcher's account in her memoirs of her sacking of Pym oozes contempt: 'In following Peter Carrington with Francis Pym as Foreign Secretary I had exchanged an amusing Whig for a gloomy one. Even the prospect of a landslide during the [1983] election made him utter dire warnings ... I hoped he would consent to become Speaker and I still believe that he would have done the job well ... But in any case he was having none of it. He preferred to go to the back-benches where he was a not very effective critic of the Government.' See Margaret Thatcher, The Downing Street Years (London: HarperCollins, 1993), pp. 306-7.

${ }^{47}$ In fact, Blair did not want to lose Clarke as a member of the cabinet and offered him several alternative posts. He was disappointed, even dismayed, when Clarke declined all of them. But Blair was not willing to see Clarke remain at the Home Office and preferred to see him on the back benches rather than in that particular office. See Alan Travis, 'Released terror suspect sealed home secretary's fate', Guardian, 6 May 2006.

${ }^{48}$ At least in connection with British politics, the phrase 'big beasts of the jungle' - or, alternatively, 'great beasts of the jungle' - appears to have originated with Sir Michael Fraser (later Lord Fraser of Kilmorack), a senior Conservative party official during the 1960s and 1970s. Another prominent Conservative - Douglas Hurd, who served as Edward Heath's political secretary and then as a cabinet minister under both Margaret Thatcher and John Major - inherited the phrase and helped give it common currency. In a letter to one of the authors, Lord Hurd writes of Fraser: 'He was full of tales of past doings of the "great beasts", usually culminating in a dramatic account of the Party conference of 1963 when they were all trumpeting in the jungle.' Although the use of the phrase in connection with politics may be relatively new, the concept itself is old. More than a century ago, Sidney Low suggested that there were 'superior and inferior classes of ministers', by which he meant ministers who counted and ministers who did not, by virtue of who they were as well as the offices they held. See Sidney Low, The Governance of England (London: T. Fisher Unwin, 1904), pp. 162-70, esp. p. 167. Anthony King made use of both the phrase and the concept in 'Ministerial Autonomy in Britain', in Michael Laver and Kenneth A. Shepsle, eds, Cabinet Ministers and Parliamentary Government (Cambridge: Cambridge University Press, 1994), pp. 203-25. King's list of big beasts for the period 1945-94 is substantially the same as, but not quite identical to, ours. According to King, the big beasts of the jungle in Clement Attlee's time were Ernest Bevin, Sir Stafford Cripps and Herbert Morrison. In a persuasive research note, Laver and Shepsle also refer to 'big beasts of the jungle', but their reference is not to individuals but to big political parties, ones that can mobilize sufficient political talent to be able, on their own, to form a government: 'Ministrables and Government Formation: Munchkins, Players and Big Beasts of the Jungle', Journal of Theoretical Politics, 12 (2000), 113-24.

${ }_{49}$ The figure of 222 is calculated from the data set out in Butler and Butler, Twentieth-Century British Political Facts 1900-2000, pp. 26-50, and Butler and Butler, British Political Facts since 1979, pp. 12-18. 
At this point, we need to clarify how we are using the term 'big beast of the jungle'. Nowadays, it is commonplace, especially among journalists, to use the phrase to denote almost any politician who stands out from the crowd and carries a modicum of political weight. Someone who has been around for a long time is especially apt to have that label attached to him. An article published in The Economist in late 2008 identified no fewer than nine big beasts, all of whom were said to be rumbling in the political jungle at that time. ${ }^{50}$ We seek to use the term more sparingly and also more precisely, to enable us to identify the biggest of the big beasts, those whom prime ministers have to take into account and whom they anger or alienate at their peril.

On our definition, a big beast of the jungle is a cabinet minister or other politician who has an unusually large amount of influence within his government or party but does not owe that influence either to his formal position or to his personal relationship with the prime minister of the day or his party leader. Big beasts may or may not be big physically, but they tend to have big personalities; they are hard to overlook. Big beasts are almost always highly intelligent and articulate, well above the general run of their contemporaries. They are also usually confident and assertive, sometimes to the point of wilfulness. Some are unpredictable and owe their influence in part to their unpredictability. It is not enough, however, for a potential big beast to have a range of impressive personal qualities if he is also a loner. To be a big beast of the jungle, he must have a substantial following in his party either in parliament or outside in the country. In addition, he must stand for something: for a specific point of view, for a particular approach to politics, or for one of his party's great interests, such as the farming interest on the Conservative side or the trade unions on Labour's. Big beasts may be highly contentious, but they can never be merely idiosyncratic: who they are and what they have to say must resonate with others. Although a big beast's standing within his own party is crucial, it also helps if the individual in question is widely recognized and highly regarded among the general public.

Big beasts of the jungle manifest their big 'beastishness' in various ways. If and when they are cabinet ministers, they usually require and are accorded a large measure of autonomy. They are allowed to get on with running their own department in their own way, largely free from external influence, including prime ministerial influence; genuinely autonomous departmental ministers are typically either big beasts or else people in charge of politically marginal departments. Big beasts are also beasts who roam widely. They are no respecters of other people's turf and are prone to become involved in the business of other people's departments. Similarly, they typically feel free to speak out on a wide range of issues, some of them having little or nothing to do with their own specialist brief. They not only feel free to speak out: they are frequently listened to. What they say counts for something. Most pertinent for the purposes of the present article is the fact that big beasts are almost invariably in a position to cause trouble. When in office, they can embarrass or even bounce the prime minister, and a threat to resign on their part, or even the possibility

\footnotetext{
(F'note continued)

The total includes only those ministers who were full members of the cabinet, not those who, in Tony Blair's time, 'attended' cabinet without being full members of it; and, obviously, it does not include the prime minister of the day, though it does include those prime ministers who, at an earlier or later stage of their career, served under another prime minister between 1957 and 2007 (namely, Home, Heath, Callaghan, Thatcher and Major).

50 Bagehot, 'Rumble in the jungle', The Economist, 11 December 2008.
} 
that they might resign, is something that a party leader or prime minister has to take into account. Prime ministers do not have to worry at all about gerbils or even very much about medium-sized beasts; but they do have to take care - or should take care - in dealing with the larger and more ferocious beasts in their vicinity.

TABLE 3 Big Beasts of the Jungle, 1957-2007

\begin{tabular}{ll}
\hline \hline Conservative & Labour \\
\hline R.A. Butler & Tony Benn \\
Kenneth Clarke & George Brown \\
Edward Heath & Gordon Brown \\
Michael Heseltine & James Callaghan \\
Sir Geoffrey Howe & Barbara Castle \\
Nigel Lawson & Tony Crosland \\
Selwyn Lloyd & Denis Healey \\
Iain Macleod & Roy Jenkins \\
Reginald Maudling & John Prescott \\
Enoch Powell & \\
Peter Walker & \\
William Whitelaw & \\
\hline \hline
\end{tabular}

Note: The list of Conservative big beasts is longer than the list of Labour big beasts principally because our main concern in this article is with big beasts who served in cabinet under the prime minister of the day, and in the halfcentury between 1957 and 2007 the Conservative party was in power for considerably longer than the Labour party. At the risk of some inconsistency, we have included Enoch Powell in the list of Conservative big beasts even though he was not really a big beast when he held cabinet office and only became one during and after his time as a member of Edward Heath's shadow cabinet. Like Michael Heseltine during the late 1980s, Powell was, so to speak, a big beast in exile. See text for explanation of italics.

Table 3 lists, by party and in alphabetical order, the big beasts on our definition who have roamed the political jungle over the past half century. The names of the very biggest beasts are set out in plain roman type; those of the beasts who were somewhat lesser in size, but were nevertheless quite big, are set out in italics. It is, of course, a matter of judgement whether any named individual should be placed in one category or the other, but few observers would probably want wholly to exclude the names of more than one or two people listed in the table or to add the names of more than one or two who are not.

An indication of how we arrived at our codings is provided by Appendix 2, which takes the form of a matrix covering those whom we have set out in plain roman type in Table 3 , those whom we have set out in italic type and those - the 'candidate big beasts', so to speak - whom we considered listing in the table but decided not to. What the candidate big beasts, those not listed in the table, have in common is that, although they possessed some (or, in a few cases, most) of the personal qualities that distinguish the really big beasts, their personal qualities did not lead them to have substantial followings either in their party or in the country at large. They may have had admirers; most of them did. But they did not have followings. Robin Cook, Peter Mandelson and Norman Tebbit, for example, were all highly intelligent, confident and assertive, and all of them undoubtedly stood for something; but they commanded very little, if anything, in the way of personal loyalty. 
We should add that, in the interests of completeness and even though this article focuses almost entirely on big beasts during the time they held cabinet office, we have listed in Table 3 the name of one individual who did carry great political weight but only after he had left office: Enoch Powell. Four prime ministers, Sir Alec Douglas-Home, Margaret Thatcher, John Major and Tony Blair, are not listed because they were by no means big beasts while they were rank-and-file cabinet ministers; Home was not a commanding figure in Macmillan's cabinet, Thatcher counted for almost nothing in Heath's, Major counted for relatively little in Thatcher's, and before becoming prime minister Blair never served as a cabinet minister and was not a even a heavyweight figure in the Labour party until a few months before being elected its leader. In contrast, Edward Heath, James Callaghan and Gordon Brown as cabinet ministers were very big beasts of the jungle long before they attained the highest office. It goes without saying that not all political beasts are of the same size throughout their whole political careers. Some gain in stature; some diminish themselves or are diminished by others. ${ }^{51}$

\section{CALCULATIONS AND MISCALCULATIONS}

It follows from the above that one important test of any prime minister's political skills is how well, or how badly, he or she calculates the strength of his or her position vis-à-vis that of other ministers and, in particular, that of any big beast or big beasts who happen to be about the place.

Harold Macmillan, as we noted earlier, had no difficulty in seeing off his chancellor in 1958: his own position was secure, and the departing chancellor, Peter Thorneycroft, although he was by no means a negligible figure (he returned to the cabinet several years later), never approached big-beast status. However, as we also noted earlier, Macmillan seriously miscalculated in 1962 when, in the 'night of the long knives', he sacked a third of his cabinet. Butchery on this scale would probably have smacked of panic and damaged Macmillan under any circumstances; but the prime minister specifically failed to notice that his then chancellor, Selwyn Lloyd, although never the biggest of beasts, had grown substantially in political stature over the preceding years. Conservative MPs had come to

51 For example, among Conservatives, Reginald Maudling had clearly emerged as a big beast by the time Harold Macmillan left office in 1963. He remained one during Sir Alec Douglas-Home's premiership and ran a close second to Edward Heath in the 1965 Conservative leadership contest. However, although he became home secretary under Heath, his flaccid ministerial style and his mounting personal difficulties undermined his position and he was in no sense a big beast during the final phase of his career. On the Labour side, Roy Jenkins was an enormous beast during the final phase of Harold Wilson's first premiership, especially following the devaluation of sterling in 1967, but his personal aloofness and alienation from the majority of his party over Europe during the early 1970s had greatly weakened his position by the time Labour returned to power in 1974. He was not a significant force as home secretary between 1974 and 1976, finishing a poor third in the 1976 Labour leadership election, and later in 1976 James Callaghan had no difficulty persuading him to quit the British political scene (to become president of the European Commission). Barbara Castle, never a very big beast, had, like Jenkins, shrunk considerably in stature by the time Labour returned to power in 1974. Callaghan in 1976 dispensed with her services. In a later generation, Peter Mandelson lacked the stature to be a big beast during his two stints as a cabinet minister under Tony Blair. But, when he returned to government under Gordon Brown in 2008, he quickly established himself as a very big beast indeed. He still lacked any substantial following in the Labour party and was not held in high regard by the general public, but he was certainly unusually intelligent, assertive and unpredictable. In addition, whereas Blair's political position had been strong vis-à-vis that of Mandelson, Brown's was exceedingly weak. 
admire his loyalty and doggedness; and, in the eyes of many on the Tory back benches, he had come personally to symbolize the desirability of fiscal discipline and restraint in public spending. Macmillan's own official biographer records that:

When the dejected Selwyn Lloyd first appeared to take his seat on the backbenches following the purge, he was cheered resoundingly by Tories, while Macmillan was greeted in chilly silence and to Opposition jeers ... [The] ghost of Selwyn Lloyd was to haunt Macmillan throughout the rest of his administration. ${ }^{52}$

Macmillan had reasons for sacking Lloyd and might have sacked him in any event; but it is clear that he grossly underestimated the political price he would have to pay - and did pay - for dismissing him. ${ }^{53}$ His successor, Sir Alec Douglas-Home, was in too weak a position to be able to consider dismissing anyone. Of the five big beasts of the Conservative jungle during the early 1960s, two, Iain Macleod and Enoch Powell, were no longer in the cabinet, having refused to serve under him, while the other three, R. A. Butler, Edward Heath and Reginald Maudling, were free to roam at will - and did. ${ }^{54}$

When the Labour party under Harold Wilson returned to power in 1964, there was only one big beast in the party's jungle apart from Wilson himself: the party's deputy leader, George Brown. Brown, however, was an enormous beast - in both senses of the word. On the one hand, he was enormously intelligent and energetic and popular in all sections of the party; Wilson during the previous year had only narrowly defeated him for the party leadership. On the other hand, he was wilful, tempestuous and frequently drunk, a man whom any prime minister would have found all but impossible to handle. Wilson handled him brilliantly, exploiting his abilities and popularity and ignoring his frequent threats of resignation until the time came when he brought doom upon himself by dissipating both his abilities and his popularity. Even when that time came - in 1968, during one of the first Wilson government's frequent economic crises - Wilson did not go so far as to dismiss Brown: he allowed him to dismiss himself. Without actually writing a letter of resignation,

52 Horne, Macmillan 1957-1986, p. 349.

${ }^{53}$ One of Macmillan's early biographers, Sir Nigel Fisher, who was himself a backbench Conservative MP at the time, uses such words and phrases in describing the night of the long knives as 'a grave political error', 'whirlwind', 'bad advice' (from the chief whip) and 'a mistake - perhaps the first serious mistake Macmillan had made during his Premiership'. Although Fisher is generally sympathetic to Macmillan, his account of the night of the long knives is extremely critical, not least in terms of the extent to which it represented an error of political judgement on Macmillan's part. See Nigel Fisher, Harold Macmillan (London: Weidenfeld and Nicolson, 1982), pp. 271-8.

${ }_{54}$ The minister who roamed most freely at will, in the sense of acting almost entirely independently of the prime minister and to some extent against the prime minister's better judgement, was Edward Heath, who as secretary of state for trade and industry insisted on promoting legislation to abolish the practice known as resale price maintenance (RPM). The extant accounts of the episode all emphasize how reluctant Home was to support Heath on RPM and the fact that the support Home did finally give him was largely a product of his political dependence on him. Home's biographer, D. R. Thorpe, notes that 'For Home it was a question of backing Heath or moving him to another department'. Thorpe adds that 'the second option was not politically viable'. Even so, Home's response to Heath's first suggestion that the government should abolish RPM was to minute, 'This is very difficult.' See Thorpe, Alec DouglasHome, p. 356, and also Heath, The Course of My Life, esp. pp. 259-60, and Campbell, Edward Heath, pp. 150-2. Campbell notes (p. 152) that 'Home was not in a position easily to deny his right-hand man and principal moderniser any measure he had set his heart on'. Home in his memoirs - The Way the Wind Blows (London: Collins, 1976) - admits to having had 'many misgivings' (p. 189). See also Richard Findley, 'The Conservative Party and Defeat: the Significance of Resale Price Maintenance for the General Election of 1964', Twentieth Century British History, 12 (2001), 327-53, p. 343. 
Brown told everyone within earshot during the midst of the crisis that he had resigned, and Wilson took him at his word. Even a biographer sympathetic to Brown and hostile to Wilson notes ruefully that when Brown went, "he did not quite do so "without a splash" ... but the subsequent waves were nowhere near so mountainous as Wilson feared and Brown hoped'. ${ }^{55}$ Indeed, Wilson had calculated aright: there were hardly any waves at all. Wilson was equally shrewd in dealing with the two big beasts who had emerged by the end of his first premiership: James Callaghan and Roy Jenkins. He was weak. They were strong. He let them alone. ${ }^{56}$

For the reasons given above, Edward Heath had no reason to concern himself with big beasts: following Iain Macleod's death, there were none in his cabinet, and he reigned supreme. In contrast, Harold Wilson's cabinet, during his brief second incarnation as prime minister, included a veritable zoo full of big beasts, including nearly one-third of all those listed in Table 3. All had served in cabinet between 1964 and 1970; all had great abilities and substantial support within the party. With the possible exception of Barbara Castle, a personal friend, Wilson could scarcely afford to lose the services of any of them. The most difficult to deal with was Tony Benn, who had been little more than a gerbil during the previous decade but by the mid 1970s was a formidable politician. Wilson again demonstrated his tactical brilliance. He appointed Benn to the important Department of Industry (while hobbling him there) and then, following the defeat of Benn's side in the 1975 Common Market referendum, demoted him to the significantly less important Department of Energy. ${ }^{57}$ When Callaghan became prime minister, he left Benn where he was and, like Wilson, hobbled him without dismissing him. At the height of his new-found power in 1976, Callaghan encouraged Roy Jenkins, who might have re-established himself as a serious rival, to depart for the European Commission in Brussels and, as we saw

55 Peter Paterson, The Life of Lord George Brown (London: Chatto \& Windus, 1993), p. 241. Wilson in his memoirs notes, with glee but probably accurately: 'Even George Brown's two closest supporters, of many years' standing, told him and other ministers that this time he had gone too far' (Wilson, Labour Government 1964-1970, p. 510).

${ }^{56}$ In the case of Jenkins, Wilson refrained from acting against him even though he knew that Jenkins and his allies were plotting against him and wanted to depose him in Jenkins's favour. See the graphic account of the Jenkins-Wilson relationship in Pimlott, Harold Wilson, pp. 488-91. In the even more remarkable case of Callaghan, Wilson refrained from acting against him even though in 1969 Callaghan semi-publicly - for all practical purposes, publicly - opposed the key element in the government's legislative programme: proposals for trade union reform based on the White Paper, In Place of Strife. In his definitive account of the In Place of Strife episode - The Battle of Downing Street (London: Charles Knight, 1970) - Peter Jenkins observes (p. 80) that 'Callaghan was challenging the leadership [i.e. the prime minister] on a clear issue, he was identifying himself with an alternative strategy; he was offering a different style of leadership. For these reasons he had no intention of resigning ... If Wilson wanted to make an issue of it at this stage he would have to sack him. The Home Secretary [Callaghan] was fairly confident that he would not be sacked.' (See also pp. 94-5.) In the event, Callaghan did not resign, Wilson did not sack him, and the In Place of Strife proposals were withdrawn.

57 See Ben Pimlott's vivid account of Benn's marginalization and then demotion - an account based on a mass of evidence - in Harold Wilson, pp. 664-8. Benn was a big beast. Had he not been a big beast, Wilson would undoubtedly have sacked him. Even so, Wilson, who was confident of his own position and also confident in his judgement of both Benn's position and his personality, treated Benn - as another member of the cabinet, Tony Crosland, reported to his wife - as a cat would treat a mouse: Susan Crosland, Tony Crosland (London: Jonathan Cape, 1982), p. 293. Wilson acknowledged Benn's big beast status in his own account of Benn's demotion: Harold Wilson, Final Term: The Labour Government 1974-1976 (London: Weidenfeld and Nicolson and Michael Joseph, 1979), pp. 143-4. He feared Benn might, after all, decide to return to the back benches, 'the last place where I wished to see him' (p. 144). 
earlier, summarily sacked Castle. ${ }^{58}$ Tony Crosland died in office soon afterwards, with the result that by the end of Callaghan's premiership only Benn and Denis Healey, among the original sextet of big beasts, remained in office. No new one emerged.

In this connection, if in no other, the premiership of Margaret Thatcher turned out to resemble Harold Macmillan's: shrewdness bordering on brilliance followed by ineptness amounting to folly. To begin with, especially during the period 1979-83, Thatcher used her dismissal power to great effect, sacking or sidelining all but one of her 'wet' critics inside the cabinet. Unsurprisingly, the one who remained was the only one who might be accounted a big beast: Peter Walker. She feared the damage Walker could cause outside the cabinet and declined to sack him, despite the fact that from time to time he was publicly critical of government policy. Walker for his part was content to stay on board and to occupy relatively minor cabinet posts. The prime minister and the big beast had a tacit - perhaps not so tacit treaty. He would not resign, and she would allow him to run his relatively minor departments in his own way and to make speeches critical of government policy provided they were expressed in suitably decorous language. As Walker put it apropos his joining the government in 1979: 'I had few illusions about the Prime Minister's motives. I knew Margaret was not going to give me a senior job. I was in the Cabinet because she thought I was safer in than out. She knew that I knew that was the reason. ${ }^{59}$ In the event, both honoured their side of the bargain, and Walker remained in the Thatcher cabinet until almost the end.

Others, however, did not remain, and the circumstances of their departures hastened, indeed probably brought about, her own departure. Thatcher simply, but grossly, miscalculated. She thought those who departed were little beasts when they were actually very big ones. She thought her position was very strong when, as we observed earlier, it had in reality become very weak, though she had failed to notice the fact. The trouble began in 1986 when she failed to go out of her way to conciliate one of her senior ministers, Michael Heseltine, in order to discourage him, first, from making trouble in public and then, ultimately, from resigning. Once outside the cabinet, Heseltine felt free, not to attack either the prime minister or the government, but to campaign among the Conservative party's membership in the country with a view to establishing a claim to the party's leadership at some time in the future. Free to roam, Heseltine was always a potential threat. In 1990, he precipitated Thatcher's departure by challenging her for the leadership.

In the meantime, she had failed to forestall the resignations of two other beasts whose stature and ferocity she had also seriously underestimated. Her chancellor, Nigel Lawson, fed up with being second-guessed by her private in-house economics adviser, Sir Alan Walters, resigned suddenly and unexpectedly in 1989. Then, during the following year, her former chancellor and foreign secretary, Sir Geoffrey Howe, demoted by this time to the (largely nominal) post of leader of the House of Commons, also resigned. He was fed up

\footnotetext{
${ }^{58}$ Callaghan's encouragement of Jenkins took the form of making it clear that he would not appoint him to the one job in the new cabinet, that of the foreign secretary, that he really wanted and would have accepted. As Callaghan's biographer notes, 'Roy Jenkins had been promised by Wilson before the leadership contest the succession to the presidency of the European Commission, but he would have forgone this if he could now move to the Foreign Office in succession to the new Prime Minister. In fact, Callaghan at once made it plain that it was to Brussels rather than to Carlton Gardens that he must go. Jenkins, with his passion for Europe and his right-wing stance on most issues, he judged, would be a divisive force in the party' (Morgan, Callaghan, p. 477). Given Jenkins's political stature and the widespread support that he still had in the Labour party, it was convenient for Callaghan that the Brussels bolt-hole was available.

${ }^{59}$ Walker, Staying Power, p. 146.
} 
with being slighted by the premier and objected conscientiously and strenuously to her increasing hostility to further European integration. His resignation speech in the House of Commons seriously weakened Thatcher's position and at the same time made it all but impossible for Heseltine not to launch his challenge against her. By November 1990, when she was driven from office, there were only three big beasts left in the Conservative jungle Heseltine, Lawson and Howe - and she had contrived to alienate all three of them. Her inadvertence, inattention and miscalculation cost her her job. ${ }^{60}$

Her successor, John Major, exercised far greater caution. He neither sacked nor precipitated the resignation of any senior minister, even though he did regard some of them as bastards, and he allowed Michael Heseltine, by now restored to office, to roam freely. Tony Blair was equally cautious. By the time he took office as prime minister in 1997, Labour had been out of office for eighteen years, and during a large part of those eighteen years the party had not looked like winning a general election. One consequence was that by 1997 there were only two big beasts in the Labour jungle - John Prescott and Gordon Brown - and Blair throughout his ten-year term of office took care not to alienate or dismiss either of them. In the case of Prescott, the task was easy: Prescott was intensely loyal and delighted to serve as Blair's deputy. In the case of Brown - one of the biggest beasts in recent history - the task was far more difficult: relations between the two men were often fraught, and Brown coveted and made no secret of the fact that he coveted - Blair's job. Blair, however, studiously resisted the temptation to sack Brown; and, fortunately for Blair, Brown proved reluctant to force the issue or precipitate an open breach. Whether or not Blair as prime minister was conscious of Macmillan's and Thatcher's miscalculations in dealing with big beasts, he certainly behaved as though he were. ${ }^{61}$ Even so, Blair in the end resigned as early as June 2007 largely because Brown was, at last, growling and baring his teeth.

A glance back at Table 1 is revealing in view of the way it relates to Table 3 . In Table 3 , the names of twenty-one big beasts of the jungle, in our understanding of the term, are set out. It is striking that, of the twenty-one, only five were either dismissed outright or constructively dismissed by the prime minister or prime ministers under whom they served - this despite the fact that most of the twenty-one were from time to time seriously at odds with their prime ministerial boss. Of those five, Barbara Castle was dismissed and Roy Jenkins was allowed to

60 Alan Watkins in A Conservative Coup takes it for granted that 'Michael Heseltine, Nigel Lawson and Geoffrey Howe were the ministers (by this time, of course, ex-ministers) who were chiefly responsible for bringing Mrs Thatcher to her current condition' (p. 4). Her 'current condition', of course, was the one in which she could be challenged and ousted. The enormity of Thatcher's folly is emphasized by Watkins and also by Robert Shepherd in The Power Brokers, chaps. 1-3. For the three big beasts' own accounts of their role in Thatcher's removal from office, see Heseltine, Life in the Jungle, chaps. 15-16; Nigel Lawson, The View from No. 11: Memoirs of a Tory Radical (London: Bantam Books, 1992), chaps. 76-7, 79, and Geoffrey Howe, Conflict of Loyalty (London: Macmillan, 1994), chaps. 40-5. With regard to Howe, Shepherd writes: 'She dared not risk sacking Howe but treated him appallingly. At the last two cabinet meetings before his resignation she had openly displayed her impatience with him when he spoke "rolling her eyes and looking at the ceiling', according to one minister' (p. 1).

61 On the strange Blair-Prescott-Brown triangle, see, among many, many other things, Rawnsley, Servants of the People; Naughtie, The Rivals; and Alastair Campbell, The Blair Years: Extracts from the Alastair Campbell Diaries (London: Hutchinson, 2007). Far from Blair being an overwhelmingly dominant prime minister, he and Brown shared power. Prescott notes in his memoirs - Prezza: My Story: Pulling No Punches (London: Headline Review, 2008), p. 303 - that Brown effectively blocked the prime minister's desire to take Britain into the European single currency and that he also 'rarely took Tony fully into his confidence as he was preparing Budgets.' Prescott also notes (p. 313) that Peter Mandelson, another minister, often referred to the three men as 'the Big Beasts'. 
go, but only when the prime minister of the day was at the height of his power and their own power was waning. In the cases of all of the other three, Selwyn Lloyd, Nigel Lawson and Sir Geoffrey Howe, the prime minister of the day paid a heavy political price for not treating them with the consideration that is due big beasts. In politics, big beasts are also dangerous beasts: Tyrannosaurus rex, not remotely Brachiosaurus.

\section{CONCLUDING REFLECTIONS}

The research conducted for this article and its substantive findings provoke two wider reflections relating to the British prime ministership. Both can easily be stated.

In the first place, our findings concerning the prevalence of big beasts in the immediate environments of most British prime ministers inevitably align us with those who are sceptical of claims that the British system is becoming significantly more 'presidential'. Of the eight prime ministers between 1957 and 2007, only Edward Heath, as we have seen, did not have to take into account the views - and the mere political presence - of one or more big beasts in his cabinet. Margaret Thatcher was unique in a different way: there were big beasts in and (later) around her cabinet, but latterly she chose to ignore the fact that they were indeed very big and therefore potentially very dangerous. A future prime minister is unlikely to want to repeat her mistakes. It is, of course, possible that occasional future prime ministers will, for all or parts of their premierships, not have to accommodate big beasts, but the concatenations of circumstances that produce such situations seem likely to be rare. In short, we are on the side of those students of Britain's 'core executive' who maintain that British government at the top comprises a set of relationships of mutual dependence and is far from being monocratic in character. In the words of Martin J. Smith, 'British government is not prime ministerial government or cabinet government. Cabinets and prime ministers act within the context of mutual dependence based on the exchange of resources with each other and with other actors and institutions within the core executive. ${ }^{62}$ We would only add the obvious point that some cabinet ministers have significantly more resources than others, by virtue of who they are, not merely by virtue of the offices they hold.

Our second reflection is this. If, as we argue, the relationship between prime ministers and big beasts is, most of the time, crucial to an understanding of British government at the top, then it would seem worthwhile for political scientists, especially those with a historical bent, to examine in detail the ways in which past prime ministers have dealt with their big beasts. What are the signs that they have recognized them as such? To which posts in cabinet have they assigned them? How, if at all, have they stroked their egos? How, if at all, have they engaged them in decision making? On matters of policy, have prime ministers allowed them to function as active initiators or, alternatively, as veto players? The unfortunate case of Margaret Thatcher is well known and well documented, but less attention has been paid to the relationships between, for example, Harold Macmillan and R. A. Butler or between James Callaghan and Denis Healey. Every commentator acknowledges that the prime minister-chancellor of the exchequer relationship is central to the workings of any British government, but the same point could be made of the prime minister-big beast relationship (especially, but not only, if a particular big beast happens also to be chancellor).

${ }^{62}$ Martin J. Smith, 'Interpreting the Rise and Fall of Margaret Thatcher: Power Dependence and the Core Executive', in R. A. W. Rhodes and Patrick Dunleavy, Prime Minister, Cabinet and Core Executive (Basingstoke, Hants.: Macmillan, 1995), p. 123. See also Martin J. Smith, The Core Executive in Britain (Basingstoke, Hants.: Macmillan, 1999), chap. 4. 
Big beasts in the British system apart, it is perhaps worth repeating the general point that whether or not the head of government of any country does or does not possess - in practice as well as in theory - the power to appoint and dismiss members of his or her administration is crucial to an understanding of how that country's government in its upper reaches actually functions. That simple fact is almost universally recognized, and yet it is also striking that most textbooks on individual countries, and even most books and articles on comparative politics, devote little or no space to addressing it. We hope that the present article, whatever else it does, may serve to heighten scholarly interest in this whole subject.

\section{APPENDIX 1}

TA B LE A $1 \quad$ Voluntary Resignations from Cabinets, 1957-2007

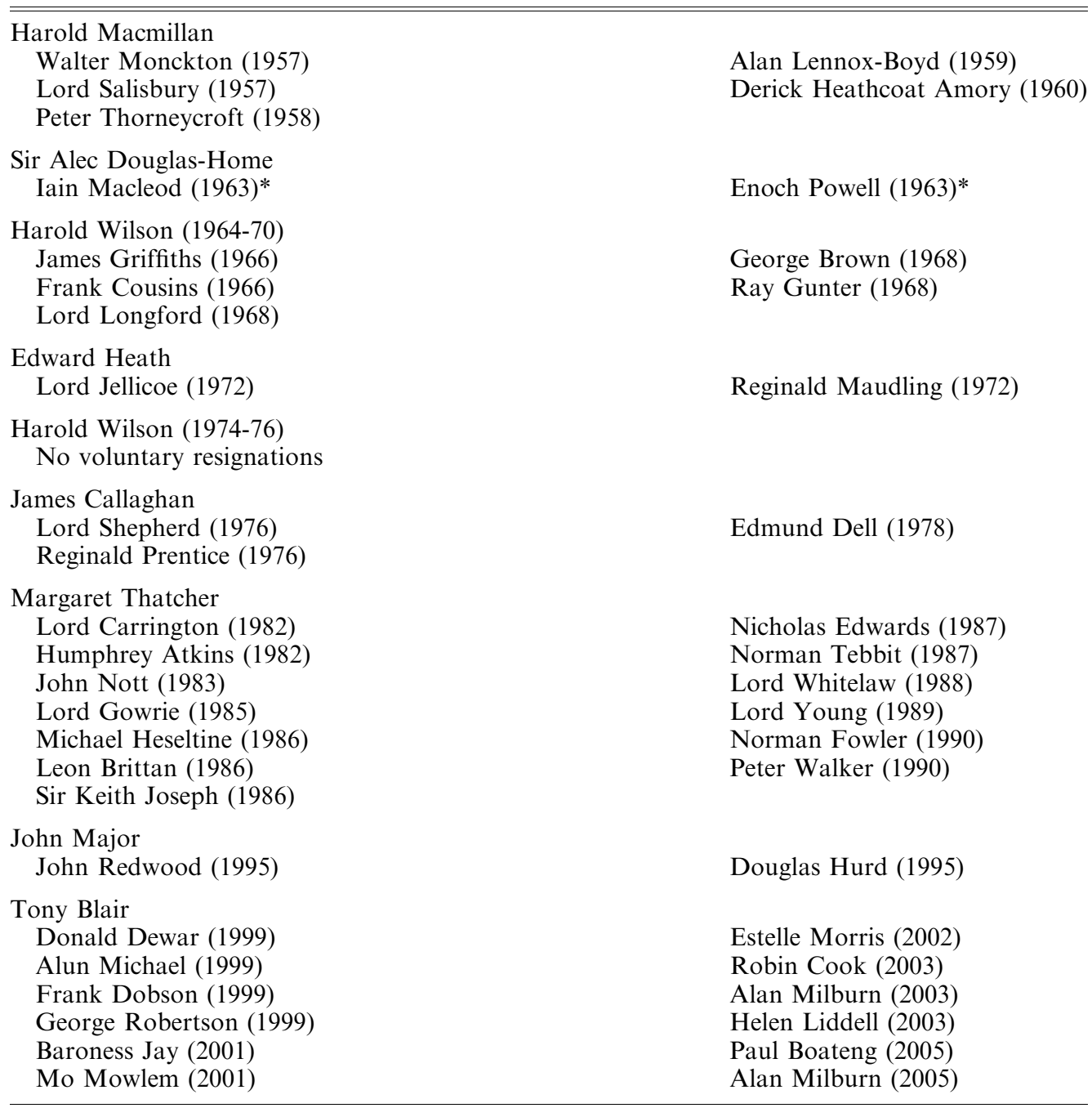

* Iain Macleod and Enoch Powell did not resign in the strict sense, but they did resign in the sense that, having been successful cabinet ministers under Harold Macmillan, they refused to stay on under his successor, Sir Alec Douglas-Home. 
APPENDIX 2

TABLE A2 Attributes of Big Beasts, 'Candidate’ Big Beasts, 1957-2007

\begin{tabular}{|c|c|c|c|c|c|c|}
\hline & $\begin{array}{l}\text { Unusually } \\
\text { intelligent }\end{array}$ & Assertive & Unpredictable & $\begin{array}{l}\text { Stood for } \\
\text { something }\end{array}$ & $\begin{array}{l}\text { Substantial } \\
\text { following in } \\
\text { his or her } \\
\text { party }\end{array}$ & $\begin{array}{l}\text { Highly } \\
\text { regarded } \\
\text { among the } \\
\text { public }\end{array}$ \\
\hline \multicolumn{7}{|l|}{ Very big beasts } \\
\hline Tony Benn & No & Yes & Yes & Yes & Yes & No \\
\hline George Brown & Yes & Yes & Yes & Yes & Yes & No \\
\hline Gordon Brown & Yes & Yes & Yes & Yes & Yes & Yes \\
\hline R.A. Butler & Yes & $?$ & No & Yes & Yes & Yes \\
\hline James Callaghan & $?$ & Yes & Yes & Yes & Yes & $?$ \\
\hline Edward Heath & Yes & Yes & No & Yes & Yes & No \\
\hline Michael Heseltine & Yes & Yes & Yes & Yes & Yes & Yes \\
\hline Denis Healey & Yes & Yes & No & Yes & Yes & $?$ \\
\hline Roy Jenkins & Yes & Yes & Yes & Yes & Yes & Yes \\
\hline Iain Macleod & Yes & Yes & Yes & Yes & Yes & No \\
\hline Reginald Maudling & Yes & No & No & Yes & Yes & No \\
\hline John Prescott & No & Yes & Yes & Yes & Yes & No \\
\hline \multicolumn{7}{|l|}{ Lesser big beasts } \\
\hline Barbara Castle & Yes & Yes & No & Yes & Yes & No \\
\hline Kenneth Clarke & Yes & Yes & Yes & Yes & Yes & $?$ \\
\hline Tony Crosland & Yes & $?$ & No & Yes & $?$ & No \\
\hline Sir Geoffrey Howe & Yes & $?$ & No & Yes & No & No \\
\hline Nigel Lawson & Yes & Yes & Yes & Yes & No & No \\
\hline Selwyn Lloyd & $\mathrm{No}$ & $?$ & No & $?$ & No & No \\
\hline Enoch Powell & Yes & Yes & Yes & Yes & Yes & Yes \\
\hline Peter Walker & Yes & Yes & No & Yes & $?$ & No \\
\hline Willie Whitelaw & Yes & No & No & $?$ & No & No \\
\hline \multicolumn{7}{|l|}{ 'Candidate' big beasts } \\
\hline David Blunkett & No & Yes & No & No & No & No \\
\hline Robin Cook & Yes & Yes & Yes & Yes & No & No \\
\hline Richard Crossman & Yes & $?$ & No & No & No & No \\
\hline Michael Foot & $?$ & No & No & Yes & No & No \\
\hline Lord Hailsham & Yes & No & Yes & No & No & No \\
\hline Douglas Hurd & Yes & No & $\mathrm{No}$ & $?$ & No & No \\
\hline Sir Keith Joseph & Yes & No & No & Yes & No & No \\
\hline Peter Mandelson & Yes & Yes & No & Yes & No & No \\
\hline Jim Prior & No & No & No & Yes & No & No \\
\hline Francis Pym & No & No & No & $?$ & No & No \\
\hline Norman Tebbit & Yes & Yes & $?$ & Yes & No & No \\
\hline
\end{tabular}

Note: In this matrix, 'Yes' indicates that, in the authors' judgement, the politician concerned possessed the relevant attribute and 'No' that he or she did not. A question mark indicates uncertainty in our minds. As indicated in the text, in a few cases it is a matter of judgement whether an individual should be classified as a very big beast or as a lesser one. For example, a case could be made out for regarding Kenneth Clarke as having been a very big beast during the last phase of the Major government. Similarly, a case could be made out for reclassifying Peter Walker and, in particular, Selwyn Lloyd as having been merely candidate big beasts rather than lesser ones. However, adjustments such as these, even if all of them were made, would not affect the core arguments set out in the text. 